\title{
Managing the Urban Environment of Manila
}

\author{
David J. Edelman \\ School of Planning, College of Design, Architecture, Art and Planning, University of Cincinnati, \\ Cincinnati, $\mathrm{OH}, \mathrm{USA}$ \\ Email: david.edelman@uc.edu
}

Received 27 January 2016; accepted 7 March 2016; published 10 March 2016

Copyright (C) 2016 by author and Scientific Research Publishing Inc.

This work is licensed under the Creative Commons Attribution International License (CC BY).

http://creativecommons.org/licenses/by/4.0/

c) (i) Open Access

\begin{abstract}
This article brings the contemporary thinking and practice of Urban Environmental Management (UEM) to the solution of real problems in a major city of a developing country in Southeast Asia. Such cities confront more pressing problems than those in the developed world and have fewer resources to deal with them. The study first considers urban issues, poverty alleviation, industry, transportation, energy, water, sewage and sanitation, and finance, and then proposes a 5-year plan to help solve the urban environmental problems of Metro Manila, the Philippines, an environmentally complex, sprawling metropolitan region with over 24 million inhabitants.
\end{abstract}

\section{Keywords}

Urban Environmental Management, Regional Planning, Developing Countries, Metro Manila

\section{Introduction}

This article focuses on the practice of Urban Environmental Management (UEM) in developing countries, which both face more immediate problems than the developed world and have fewer resources to deal with them. The study is the report of a graduate level workshop that took place at the School of Planning, College of Design, Architecture, Art and Planning, University of Cincinnati, USA from August through December 2015. The objective of the workshop was to prepare students to work overseas in data-poor environments as professional consulting planners. Several lectures were given to set the framework for the class of 15 students to operate in sector-level teams (poverty alleviation, industry, transportation, energy, water, sewage and sanitation, finance) preparing a 5-year plan to help solve the urban environmental problems of Metro Manila, the Philippines, an environmentally complex, sprawling metropolitan region in Southeast Asia with over 24 million inhabitants (Demographia, 2015), utilizing a real-world data base and a limited budget. This project formed the majority of class work culminating in the completion of a professional quality document. 
As urban environments increasingly become a central issue in the twenty-first century, compounded by rapid urbanization and climate change, the adoption of urban environmental management initiatives is crucial. That is because urban environmental management provides a framework to mainstream a multitude of issues confronting urban areas through urban planning and development. Different instruments related to the process, planning and management of urban environmental challenges can help cities to promote urban environmental management. The success of these instruments, in addition to other interventions, will prove whether progress is being made in preventing, mitigating, and managing urban environmental challenges (Cities Alliance, 2007).

Urban environmental management provides a framework to promote sustainable urban environments. As indicated earlier, urban areas throughout history have been centers of prosperity and at the same time of concentrated poverty. With more than half of the world's population now living in urban areas, and with projections of $70 \%$ by 2050 (United Nations Population Fund, 2007), urban environmental management will remain relevant and crucial for managing urban environmental challenges. This is all the more so as urban areas remain critical to promote sustainable development in the 21st century. Urban areas occupy only $2 \%$ of the world's land area; yet they are responsible for the consumption of over $75 \%$ of the Earth's resources. Thay also produce $75 \%$ of the total waste generated globally (Girardet, 1999; Desai and Riddlestone, 2002). Urban environmental problems are "wicked” (Webber, 1973) and require imminent action (Royal Commission on Environmental Pollution, 2007). With rapid urbanization and climate change, it is apparent that urban challenges will become even more severe if action is not taken now.

Like many developing countries, the Philippines are experiencing rapid urbanization. This is accompanied by several challenges that require managing its urban environment. Moreover, this rapid urbanization has not generated the accompanying prosperity that characterizes countries like China, India, Thailand and Vietnam (Steele, 2014). Rather, the Philippines is facing issues with poverty, transportation, industry, sewage and sanitation, water supply and financing urban development as the country grows and urbanizes. At the national and local levels, different efforts have been attempted to manage these urban environmental difficulties; yet the urban challenges remain daunting.

\section{Poverty Alleviation}

In creating an environmental plan for an urban area, especially in a developing country, it is important to consider all the actors in the city and how they use their environment. Often, low-income city dwellers are underrepresented in plans and city institutions. However, it would be remiss not to consider this population in Metro Manila as 3.9\% of Metro Manila’s population is considered to be living in poverty (The Borgen Project, 2013). Since the late 1980s, the Philippines have experienced rapid population growth and slow per capita economic growth, although the latter has increased much more rapidly in recent years. These factors, combined with ineffective trickle-down economic policies and the lack of robust social programs to address the poor, have led to high levels of income inequality (Buentjen, 2011). This disparity is seen blatantly in Metro Manila.

In order to address this disparity, the National Economic and Development Authority of the Philippines created the Philippine Development Plan 2011-2016 in 2011. The plan's priorities lie in inclusive economic growth and improvements in government transparency (NEDA, 2011). This plan, known as the government's social contract with the Filipino people, sets a vision for development and poverty alleviation programming in the whole of the country. While powerful in creating a unified message, the plan does little to hone in on specific issues of urban poverty in Metro Manila and, therefore, has not created sustainable programs to address the inequality. In Metro Manila, three priority problem areas were identified by the poverty alleviation team: housing conditions in the informal settlements, access to clean water, and lack of job security in the informal sector. These are treated in order below.

\subsection{Problem: Housing Conditions in Informal Settlements}

Philippine urbanization has a distinct hierarchy of settlements. The Metro Manila landscape is characterized by high rises of moderate and high income citizens and the informal slum settlements of those citizens living in poverty. The settlement hierarchy is very evident with a high concentration of population in a few urban centers.

Deprivation in Metro Manila is income-based, as noted, and infrastructure-based. The region has been unprepared for the rapid rate and high level of urbanization that have exerted tremendous pressure on the megacity's infrastructure and basic services. This lack of access to infrastructure and basic services has led to the growth of 
unregulated settlements or slums. The Philippine government has tolerated the growth of slums since the housing market has not been able to keep pace with urban housing demand, especially in Metro Manila (World Bank, 2011).

Metro Manila, like other megacities in developing countries, has been experiencing rapid urban growth, high population densities, increasing poverty and an escalation of land prices. These forces have led to a critical shortage of affordable land for housing, leaving the majority of the urban poor to live under a constant threat of eviction in unauthorized settlements (Porio, 2011). These forces have largely contributed to the proliferation of urban poor communities in the metropolis. Tenure insecurity creates cycles of vulnerability, which are magnified in settlements prone to natural disasters.

\subsection{Solution: Land Titling for Slum Dwelling Security}

This project would be in partnership with USAID, the US Agency for International Development. USAID has been able to implement a similar project in Tanzania that kicked off in 2014. This approach uses mobile technology for land mapping. The "app” approach combines relatively inexpensive and readily available mobile technologies (e.g., GPS/GNSS-enabled smart phones and tablets) with broadly participatory crowd-sourced data collection methods in underserved settings. The approach would train local community members to use technology developed for this purpose to gather land rights and tenure information (USAID, 2014).

An application with the ability to run on any smart device would be developed with the aim of creating a participatory approach for capturing land rights information, as well as providing a low cost methodology for quickly building a reliable database of land rights claims. A smart phone or handset device would be needed for the mapping. Land tenure is a major issue in Metro Manila; therefore, it would be important for informal settlement dwellers to be educated on the importance of land titling, rather than staying in poor and unstable conditions.

This application might be particularly helpful to the Government of the Philippines as an alternative to more traditional, and costlier, land administration interventions. Formal land administration systems in the Philippines have generally not met the need for accessible, cost effective and appropriately nuanced land registration. As a result, large majorities of informal settlements live without formalized rights to land and other valuable resources. This lack of documentation constrains the ability of individuals and communities to develop a sense of belonging, resulting in deprived accommodation and social instabilities among poor citizens in Metro Manila. Thus, this app would increase land tenure security for slum dwellers.

\subsection{Problem: Inadequate Housing and Slum Proliferation}

The major issue with poor housing and slums is related to the growing number of urban residents and how housing and infrastructure services can be financed for future urban generations. Upgrading housing and slums can be complex and unclear, because several interrelated components, including physical and social environments, must be addressed that entail significantly different financial consequences: a) infrastructure components like housing, water, sanitation, roads and footpaths, storm water drainage, lighting or public phones; b) service components like waste collection, schools, medical centers and, c) other services such as community buildings, public spaces, and peace building and poverty reduction programs. Informal settlements are unplanned, densely populated, and neglected parts of cities where living conditions are extremely poor (Sticzay, 2015). Much of the housing stock in these informal settlements is inadequate and unsafe; therefore, physical improvements to housing are needed, in partnership with community building. The process of slum upgrading involves the improvement of both physical and social environments. Projects show that tri-sector partnerships, including the state, private and nonprofit sectors, have to cooperate in order to manage effectively a slum upgrading program. Even though the enumerated parties show commitment, the urgent needs of individual slum dwellers and local communities also have to be considered. In order to make slum upgrading successful in the long term, enduring and strategic planning must be addressed in all financial, institutional and regulatory decisions (Programa Vivenda, 2015).

Living in bad environments deprives people of a quality of life enabling them to have better incomes and gainful employment. In particular, poor environments lower the physical and mental health of households, which adversely affects productivity, lowers the performance of children in schools and increases vulnerability to crime and violence (World Bank Annual Report, 2011). As relocation is not always the favored alternative, slum upgrading and improving the informal housing stock represent viable approaches. That is especially true 
when considering that poor families living in Metro Manila often use their own savings, as well as their own labor, for the construction and refurbishment of their houses. Nevertheless, poor families need to be enabled to help themselves.

\subsection{Solution: Slum Upgrading Program}

The project proposed here, the Slum Upgrading Project (SUP), is an initiative of private investors, international aid organizations, and local authorities with the aim of creating small offices that would be in-stalled in the informal settlement areas. Slum upgrading projects are very popular in São Paulo, Brazil. Projects like "Programa Vivenda” have already helped around 100 informal settlements across the deprived areas of the city with the refurbishment of units according to their necessity and priority. With economic support and an affordable payback period, this is an excellent alternative for the slum dwellers of Metro Manila to improve their living conditions. These offices would offer to the community credit line facilitation with a maximum cap of $\$ 5000$ per household to upgrade living conditions, with a payback expectation of 10 years. The office units would consist of a team of young architects, engineers and professionals in the construction field, who would execute the upgrading quickly and effectively in the informal settlements. At the same time, training for the participants would be offered to improve construction techniques and generate economic growth inside the informal settlement areas.

The offices would be built of sustainable materials in a strategic location that would be easily accessible to the participants. In the office, there would be one architect and one engineer, who would lead the office, with two assistants and one administrative person. The project would focus on the areas of the Metro Manila with the highest number of informal settlements. Offices would be built in the following cities: Pasay City, City of Muntinlupa and Mandaluyong City (Nakamura, 2009). The implementation of the project would take ten years with the objective of building five offices that would assist and support the local community.

\subsection{Problem: Limited Access to Clean Water}

People living in slums have limited access to potable water for a variety of reasons, including poor infra-structure and polluted water sources. In order to meet basic needs of the slum dwellers and prevent water-borne illnesses, it is important to provide a low-cost option to allow them access to clean water.

\subsection{Solution: Clay Water Filters for Clean Water Access}

Providing water infrastructure to informal settlements faces many challenges and is very expensive. In order provide a quick solution to the problem at hand and prevent illness, providing filters as a way to treat water is the best route. A US-based non-profit called Potters for Peace has pioneered a model of making and distributing low-cost ceramic clay water filters. They reject the "hand-out" model and in-stead opt to engage community members. They assist communities in making small production and distribution facilities. The Potters for Peace model is so successfully because it not only provides a means to get clean water, but it also provides economic development for neighborhoods. Using locally sourced clay, and training community members to construct the water filters, ensures that it is a low-cost and sustainable method. These clay filters have been used widely throughout South America and other parts of the developing world. Collaboration with Potters for Peace would be necessary in implementing this project, as it would provide the support and knowledge to develop and establish this project in the Philip-pines.

\subsection{Problem: Poverty and the Informal Sector}

A survey to identify citizens’ pressing concerns in Metro Manila found that low-income residents identified lack of job security and insufficient financial resources as top concerns (Illy, 1986). Lack of job security and lack of access to capital are rampant among low-income populations, many of whom participate in the informal work sector. In depressed settlements, $16 \%$ define their work status as unregistered, $18.6 \%$ consider themselves part of the informal economy, 39\% are unemployed and 16.7\% work part-time (Ragragio, 2003). Many poor individuals fluctuate between various job statuses. The informal sector consists of, but is not limited to, vending, domestic housework, construction work, handcrafting and self-employment. Throughout the past few decades, street vendors have been viewed as a menace to the urban landscape by the government. Historically, government programs focused on relocating and criminalizing informal sector workers, rather than addressing the 
problem through structural changes (Illy, 1986). In recent years, the government has passed legislation, such as the "Magna Carta for Workers in the Informal Economy (2013)" and House Bill 968, "An Act Providing for the Security and Protection of Vendors in the Workplace and for Other Purposes (2012)" that have, in theory, provided for the security of informal sector workers. These acts provided guidance on including the informal sector in the policy formation process on the local government level; however, they have not been adopted by many local governmental units (LGUs). To ensure job security in the informal sector, policies created at the national level need to be implemented at the local government level. In order to have these policies enacted by LGUs, advocacy efforts are needed. There is a great representational gap that exists among participants in the informal economy. Due to this gap, it is difficult for the informal sector workers to advocate for their protection, for access to capital, for training programs and for other social services (Ragragio, 2003).

\subsection{Solution: Department of Labor and Employment Program for Informal Sector Workers: An Evaluation and Plan}

The verbiage surrounding the informal work sector has improved considerably during the last decade with legislation such as the "Magna Carta for Workers in the Informal Economy (2013)" and House Bill 968, "An Act Providing for the Security and Protection of Vendors in the Workplace and for Other Pur-poses (2012).” However, this legislation has had little effect on the ground.

The Department of Labor and Employment (DOLE) has been a key participant in designing initiatives to support the informal economy and protect workers (Casanova-Dorotan et al., 2010). In 2007, DOLE, in partnership with the local governmental units (LGUs), UNDP and the International Labor Organization (ILO), implemented Unlad Kabuhayan Programme Laban saKahirapan (DOLE, 2007). The Worktrep program aimed to bring together members of the informal economy and representatives from LGUs to collaborate and improve the socio-economic status of the informal sector (IS) workers. Worktrep is an acronym for "Work-entrepreneur." DOLE relies heavily on LGUs as the program implementing partners. In order to attract and train them to participate in the Worktreps program, DOLE provides capability-building training and an orientation to introduce the LGU workers to the program.

The LGUs are tasked with implementing four primary services, according to DOLE: 1) training services that cover production and business management skills, as well as occupational safety, preventive health practices and confidence building; 2) assistance to allow IS workers to access the market, credit and technology; 3) access to the government's insurance schemes for health and social protections; and 4) the provision of networking services allowing IS workers to obtain representation in government and create linkages with private sector partners (Ibid.).

The Worktrep program is a novel initiative that focuses on two important aspects of engaging the informal sector workers: capacity and financial skills building and ability to organize, advocate, and work with the LGUs. While the program was introduced in 2007, there is little literature on the success, challenges or outcomes of the implementation. With that fact in mind, a program evaluation is necessary to study the outcomes and determine the direction of the program going forth.

The Organization for Economic Co-operation and Development's Development Assistance Committee established Principles for Evaluation of Development Assistance (OECD, 2015). These principles guide an evaluation process of development programs and include themes such as relevance, effectiveness, efficiency, impact and sustainability. Each theme contains guiding questions to use in the investigation. In order to implement this project, an outside strategic planning and evaluation consulting firm would be hired by DOLE. Using an outside firm would increase transparency and ensure unbiased results. Once the program evaluation is complete, employees at DOLE and representatives from all of the LGUs should work to identify any major changes needed to make the program more effective to implement further as the second edition of Worktreps. It is anticipated that the evaluation process would take approximately one to one and a half years. The strategic analysis and planning for the second edition of Worktreps would take one year, and would be followed by a pilot project and then full implementation.

\subsection{Problem: Gender and the Informal Sector}

Women constitute over half of the informal economy in Metro Manila (Frianeza, 2012). It has been stressed in 
recent years that women's full participation in all aspects of life-economic, political, and otherwise-is key for the successful development of a country. Women are often relegated to the informal economy due to cultural constructs that require them to complete household responsibilities and stifle their chances of obtaining a high level of education. As a result, the informal economy provides an opportunity for women to work around their family obligations in low-skill jobs (Moser and McIlwaine, 1997). Many of these women take advantage of their situation by establishing home-based enterprises as well. However, they are the most vulnerable population within the informal sector economy, and many lack the ability to access credit or start-up capital (Bonnin, 2004).

\subsection{Solution: Village Savings and Loan Associations (VSLAs) for Women's Economic Empowerment}

Women in the informal economy face challenges and unequal opportunity, leaving them more vulnerable than their male counterparts. Based on this knowledge, it is critical that Metro Manila focus on engaging women in the informal sector work force and providing them with the financial and social capital to participate actively in the sector, advocate for themselves and learn additional skills. Microfinance institutions have been operating around the world, providing low interest loans to low and moderate income individuals. This model has been very successful, as is evident with the Grameen Foundation, which has worked extensively in Bangladesh, India and other developing countries around the world to bring people out of poverty (Grameen Foundation, 2013). However, many microfinance institutions (MFIs) are more suited to catering to those individuals who already own small businesses and those who have basic education and knowledge about lending. MFIs also only provide credit to their clients, whereas many poor people need access to more than just credit; i.e., they need to have the ability to save (VSL Associates, 2015).

A new model of microfinance that includes this savings component was pioneered by the international non-profit CARE in 2000. This model is known as the Village Savings and Loans Association program or VSLA, for short (Hendricks, 2011). The VSLA model was created to fill the gap between services being offered by microfinance institutions and the very poor. Through creating groups of VSLAs, poor people have access to save a minimal amount each week and then apply for loans from the association's bank. Lauren Hendricks, the Executive Director of Access Africa, a CARE Initiative, explains that VSLA participants saved 10 cents each week and were able to borrow \$5. In the second year, the participants would have worked up to saving around $\$ 1$ to $\$ 2$ a week with the ability to borrow $\$ 30$ to $\$ 40$ (Ibid.). In that sense, the VSLAs provide a launching platform for individuals to start saving and receiving loans to prepare them for a formalized microfinance system in a year or two. As a result, VLSAs are a strong approach to engaging women in the informal economy and empowering them socially and economically.

\section{Industry}

\subsection{Existing Economic Conditions}

For most of its history, agriculture has been the main industry in the Philippines, and this is true in all seventeen regions of the country. After food products and food processing, mining is the second major industry. With regard to manufacturing, electronics are the most exported, but also the most imported, products in the country. In December 2014, 49.5\% of the total exports of the month were from this sector. Minerals and machinery are other major imports of the country (Economy of the Philippines, 2015).

Between 1960 and 2012, the Philippines experienced a steady decline in the share of agriculture in total output and employment. "In other developing countries, the decline in the share of agriculture is typical-ly picked up by the industrial sector. In the case of the Philippines, this was picked up by the services sector.” According to the CIA's World Factbook (2015), in 2011, more than half of the economy was based on the services sector. The agriculture sector had 33\% and the manufacturing sector had a 15\% share. In 2012, services accounted for $57.1 \%$ of GDP, compared to $31.1 \%$ for industry and $11.8 \%$ for agriculture. In the same year, 52.5\% of the labor force was employed in services, $15.4 \%$ in industry, and $32.2 \%$ in agriculture. The importance of the services sector is also reflected in the external (balance of payments) accounts of the Philippines, which show a deficit on the trade in goods account and a surplus on the trade in services account (Lee, 2014).

The Philippine government provides incentives for private institutions to encourage public-private partnerships for financing construction, operation and maintenance of public infrastructure, and development projects. 
Despite the restrictions that the country's 1987 Constitution and other laws set for foreign ownership, the government is encouraging foreign interests to "invest in the country with the businesses that improve employment opportunities, develop productivity of the sources, heighten the value and volume of the exports and provide opportunities for the future developments in the economy (CIA, 2015).” The top trading partners of the Philippines are Japan, the US, China, Hong Kong and Singapore (Philippines, 2015). Since the Philippines is experiencing growth in some of its industrial sectors and turning into an investment hub for the region, there are multiple stakeholders, development companies and banks from these countries that are willing to invest in Philippine industry.

Metro Manila, as the capital of the country, is the most significant metropolitan region in the Philippines. Due to the very centralized economy of the country, most of the businesses and major companies are located here. This investment focus on Metro Manila provides the NCR with most of the country's infrastructure required by businesses and, therefore, reduces the cost of doing business there. Compared to the rest of the country, Metro Manila has a lower percentage of manufacturing and higher percentages of tourism, business, finance and transportation in its shares of output by industry. The trade and tourism industry, with a 31.4\% share, is the most important industry of the NCR. Business and finance, with 28.6\%, and local/non-market, with $15.6 \%$ follow (Economy of the Philippines, 2015).

With the above mentioned strengths and opportunities that the Philippines have for industrial investment, there are some weakness and threats in this sector as well. "The Executive Opinion survey, conducted annually by the World Economic Forum, considered corruption as the most severe impediment to business in the country in 2014 (17.6\% of respondents), followed by inadequate infrastructure supply (15.9\%), tax regulations (13.3\%) and inefficient government bureaucracy (12.6\%).” From the environmental view, pollution, especially in the largest cities such as Metro Manila, is the main problem of Philippine industry. Unemployment and population growth are other major issues. Metro Manila is the city with the densest population, and a considerable number of people seek better job opportunities in the capital. However, employment in the NCR has increased by only $5 \%$ from 2009 to 2014 (Brookings Institution, 2015).

\subsection{Economic Outlook}

Due to the constant recent increases in private consumption, improvement in exports and a stable in-vestment climate in the Philippines, the country's economy has expanded. With a lower employment rate, modest inflation and overseas Philippine remittances, there has been growth in GDP. The average annual rate of growth is $1 \%$ and is projected to grow by more than $4 \%$ per year over the long-term based on projections of the National Economic and Development Authority (NEDA) of the Philippines. However, this strong GDP increase is assumes a fixed annual population growth rate of 1.89\% (NEDA, 2014).

The economy of the Philippines is doing quite well when compared to its neighbors. Indonesia, with an annual GDP growth rate of $6.3 \%$, is the only one experiencing better progress. Malaysia's growth is at a rate much the same as the Philippines, and Thailand, with a 2.4\% annual increase in GDP, is growing more slowly (Oxford Business Group, 2015). The industry and services sectors, like the other parts of the economy, are continuing to grow. However, this growth needs to be sustained. The international market for the Philippines in the rapidly growing economy of East Asia is a key point in its improvement. Innovation in industry and services with the creation of new products linking different sectors, as well as optimizing productivity, innovative strategies and policies are some factors that can have a great impact in the growth of these sectors (NEDA, 2014).

There is evidence to support the statement that, "of all sectors, the (Business Process Outsourcing) BPO industry tops the list for size and growth trajectory, providing employment opportunities and encouraging foreign investments into the country (Manila Bulletin, 2015; also see Figure 1).” This follows the shift to service based industry in the economy of the country. Currently, there are more than one million employees in BPO and related IT sectors in the Philippines. With the rapid growth of these sectors, the World Bank projects up to \$55 billion USD total income by 2020 and the addition of 1.5 million new jobs. Compounded by additional favorable conditions such as a significant skilled young population and lower labor costs compared to the rest of East Asia, there is a positive outlook here, as well as incentives for more investment, and, therefore, growth in these sectors (Romualdez, 2015). For Filipinos, the higher salaries from working in call centers make these positions desirable, even with the difficulties that may arise because of nighttime working hours and the accompanying necessary changes in lifestyle. 


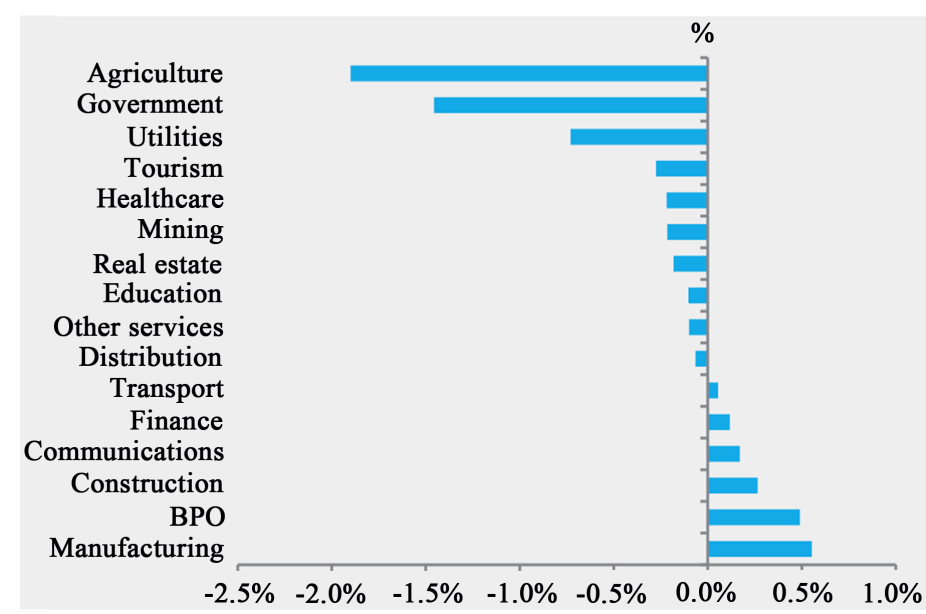

Figure 1. Philippine employment by sector 1980-2012. Source: Oxford Economics/Haver Analytics, 2015.

\subsection{The Rise of the Business Process Outsourcing Sector}

Business process outsourcing (BPO) involves contracting a third-party provider to execute specific business services such as back-of-office operations. The first BPO call center in the Philippines began serving foreign customers in 1997. It was preceded, and partly made possible by, the deregulation of the telecommunications industry in 1995. The Philippines garnered 6\% of the global BPO market in 2007, and it climbed to $10 \%$ in 2012 (Deloitte, 2014). The largest BPO customer-base is comprised of companies that are based in the United States, including Accenture (\$648.6 million USD) Convergys (\$396.6 million USD) and JPMorgan Chase Bank N.APhilippine Global Service Center (\$160.8 million USD) (Newsbytes, 2014).

The success of this sector in the Philippines can be attributed to the hospitable nature of Filipinos, which translates into excellent customer service; its cultural affinity with the US, which results in the acquaintance with and usage of American English and idioms, and, finally, a highly educated workforce that has the aptitude to function in domains like information technology, finance and animation.

A federal investment of $\$ 30.6$ million USD over 8 years (2006 to 2014) financed the business skills training for call center employees (Lee, 2014). In acknowledgement of the dependent relationship between exceptional English skills and the success of BPO endeavors, the government also led an initiative to institute the National Proficiency Exam in order to ensure that teachers are proficient and can instruct those who are potential BPO employees in that language.

The federal government has redirected its support, including funding and marketing efforts, to grow the industry in "Next Wave Cities (NWCs)" such as Baguio City, Davao City and Dumaguete. NWCs are cities located outside of Metro Manila that have experienced significant economic growth and have been identified as having the capacity to sustain and amplify those gains for the overall advancement of the country. This approach reflects the federal government's strategic priority to disperse wealth and job opportunities beyond the NRC proper. Mature and startup BPO companies alike are gradually relocating due to "the rising cost of rent, manpower, and power-generation (in Manila) (Ibid.)".

Disinvestment on the part of the federal government is not a sign that the market is cooling in Metro Manila. In fact, as of 2014, Metro Manila has become the second largest destination for companies seeking BPO services. As a proven vehicle for economic success, the position of BPO enterprises in the region's job creation agenda should be reinforced. Metro Manila is the market leader and, therefore, has the clout and experience to expand the breadth of its BPO services into new categories like health care.

\subsection{Priorities}

Manila main industrial initiative for the next five years, then, should be to implement the following projects in order to reinforce the city as a BPO:

- Establish a call center in Mandaluyong near its network of universities and technical schools; 
- Offer job training for new and current employees;

- Secure Aetna or Anthem as a BPO client;

- Perform a study to determine the viability of medical tourism in Manila, and

- Develop a superblock in the south to serve as the hub for expansion into health care BPO’s.

\section{Transportation}

\subsection{History and Context}

Serving the largest urban population in the country, the Metro Manila transportation system faces the difficult challenge of connecting its 17 local government units (LGU). At present, those connections comprise two LRT lines, one MRT line, an extensive system of local roads and highways for private automobiles, tricycles, jeepneys, buses, bicycles, pedicabs, ferries and pedestrian routes. Road transportation mobilizes $98 \%$ of vehicle passenger traffic in the Philippines (Asian Development Bank, 2012), and its overall dominance in Metro Manila makes it the sector in which changes and improvements will have the greatest impact in the region.

The population and economic growth that Metro Manila has experienced during the last few decades has resulted in accelerated automobile ownership and, with this, increases in congestion (Asian Development Bank, 2012), pollution (Robles, 2012) and costly commute times. An Asian Development Bank report estimates 4.6\% of GDP losses in congestion, (ADB, 2012; Buco and Buco, 2009; Robles, 2012), and traffic accidents (Flor, n. d.). As of 2007, the leading form of motor vehicles registered in the country was Motorcycles and Tricycles, which constituted approximately $48 \%$ of all registered motorized vehicles, followed by Utility Vehicles (including jeepneys), which were approximately $29 \%$, Automobiles being 14\%, Sports Utility Vehicles accounting for $3 \%$, Buses $0.5 \%$, and Trailers accounting for $0.4 \%$ of all registered motorized vehicles in the country (Ibid.).

The issues related to motorized vehicles are expected to escalate if a change in the current transportation system does not occur. The Philippines Land Transportation Office reported that the number of vehicle registrations has been growing at a rate of $6 \%$ per year (World Bank, 2011). Furthermore, population growth in Metro Manila over recent decades has been rapidly forming a belt-like corridor surrounding the city center (Murakami and Palijon, 2005), calling for more efficient, sustainable, and health-conscious means to connect inner-metropolitan populations in a way that does not further threaten public health or cause more degradation to the environment (as the proliferation of subdivision construction is contributing to land degradation and flooding as discussed by Murakami and Palijon, 2005).

The focus of the national government for the transportation sector has been influenced by the major decentralization process marking recent decades (Porio, 2012). This decentralization has resulted in the devolution of power and service-provision from the national government to the local government units (LGUs), which has placed communities closer to their authorities, but also strengthened political elites and corruption. Furthermore, this has left some LGUs unequipped and unprepared to undertake transportation planning roles that require greater (regional) vision, coordination and funding. The weak local management of transportation planning efforts has contributed to deficiencies in the disbursement of infrastructure funds, leaving $44 \%$ of the Department of Public Works and Highways (DPWH) available budget unused in 2007, despite the substantial demands for projects addressing transportation issues (Asian Development Bank, 2012).

The decentralization process has also placed emphasis on distributing national infrastructure efforts more evenly throughout the archipelago, which has translated into efforts to build more highways and national roads with a goal to pave all national roads by 2016 (Royal Gazette, 2015). The ambitious undertaking of consolidating a road network linking vast amounts of unconnected land has removed the focus from resolving the complex transportation problems of Metro Manila. This is visible by looking at the regional breakdown of DPWH funds dedicated to infrastructure for fiscal year 2015, which allocated $8.8 \%$ of its $\$ 4.5$ billion USD budget to the National Capital Region as opposed to other regions requiring more complex projects and receiving from $18 \%$ to 29.3\% of the DPWH funds (DPWH, 2015) (see Figure 2). The reduced presence of national funds and challenged local management of transportation initiatives has resulted in the greater presence of privately-led projects initiated through unsolicited proposals to LGU's and also via public private partnerships (Asian Development Bank, 2012). Also, the strong foreign-investment led transportation infrastructure culture that predominated in the Philippines in the 1990's is still significant (Donaldson et al., 1997), in addition to foreign aid having been added to the mix of non-national government funding for transportation projects in the region.

The fast population growth, weak, underfunded and disconnected local-level transportation planning, plus the 
FY 2015 DPWH Budget:

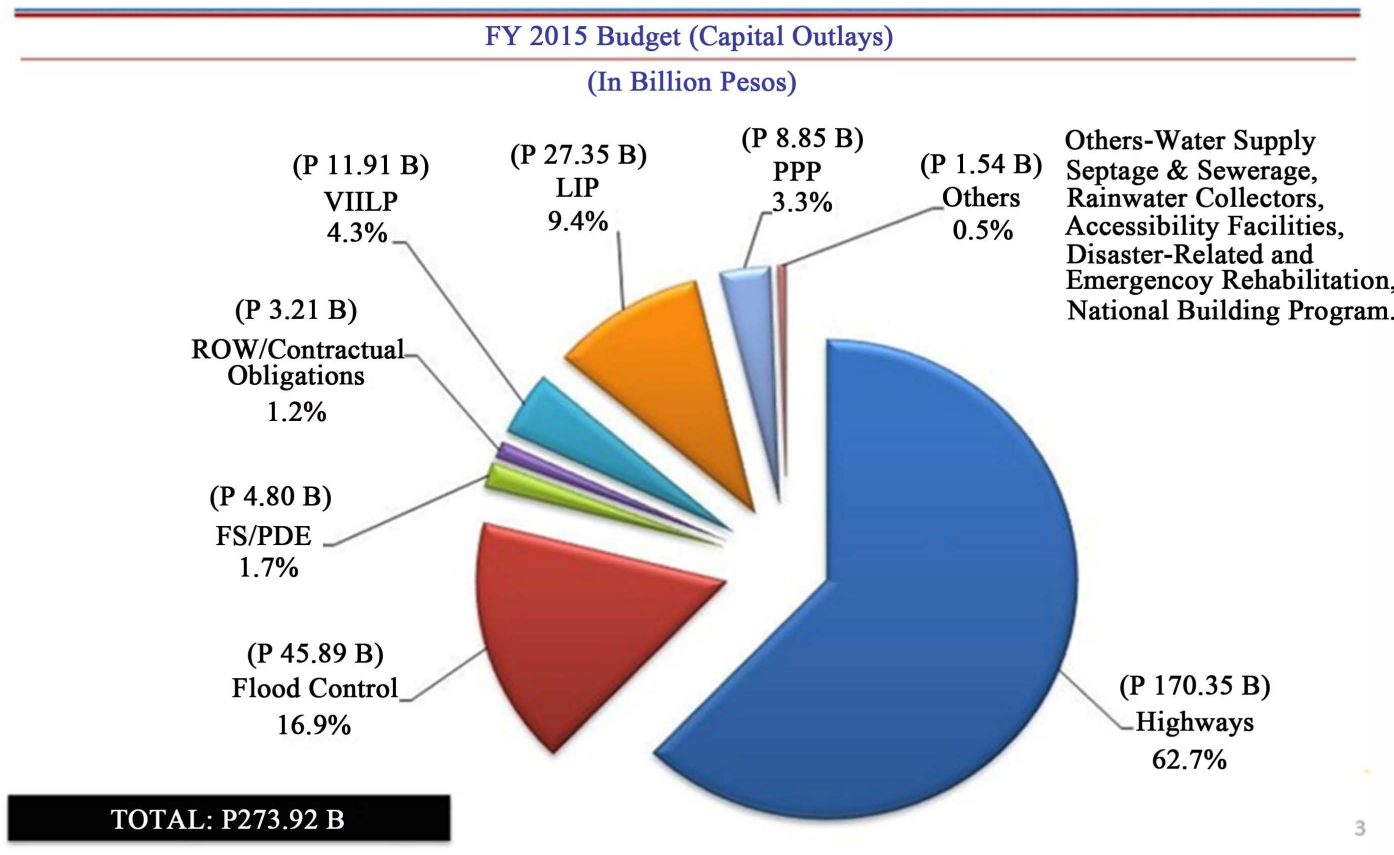

DPWH Infrastructure Program:

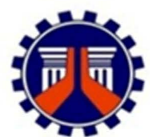

Figure 2. DPWH chart-shows 63\% of DPWH fiscal year funds allocated to highway development. Source: Department of Public Works and Highways, n. d.

disproportionately car-focused transportation vision have left the fastest growing region of the country, Metro Manila, with a transportation system unable to keep up with the demand of its growing population and 3 million daily commuters (Robles, 2012). Furthermore, the proposed solution by the national government, reflected by the large percentage of spending for highways-63\% of the FY 2015 budget as shown in Figure 2, to construct more highways, is a key contributor, rather than a solution to these problems.

The current LRT and MRT lines are positioned to serve mid- and long-distance trips, but are extremely over capacity with more than 450,000 passengers a day utilizing a system designed only for 350,000, even with capacities recently expanded (Railway Gazette International, 2007). Despite the additions of planned rail extensions for Line 4 and Line 6 of the existing rail system, as well as the Manila-Calabarzon Express line (MCX), the majority of the city's congestion issues lie in the number of motor vehicles flooding the road infrastructure of the region. Furthermore, the lack of efficient and well defined collective transportation means to cover shortto mid-distance trips results in people taking recourse to unsustainable, inefficient and polluting car or jeepney trips (see Figure 3), or further adding to over-capacity problems in the major rail systems.

\subsection{Solutions}

Upon analysis of the issues, the transportation proposal consists of three main initiatives.

- Short-Term Initiative-Consisting of 5 years, in this phase the focus is on the most prevalent modes of transportation in the region: jeepneys and tricycles. Due to the cultural and economic significance of these vehicles, their general form and function would be preserved, but these vehicles would transition away from diesel engines towards electric models. This would help reduce the nation's reliance on foreign fuel and have the greatest impact within a short period of time. 


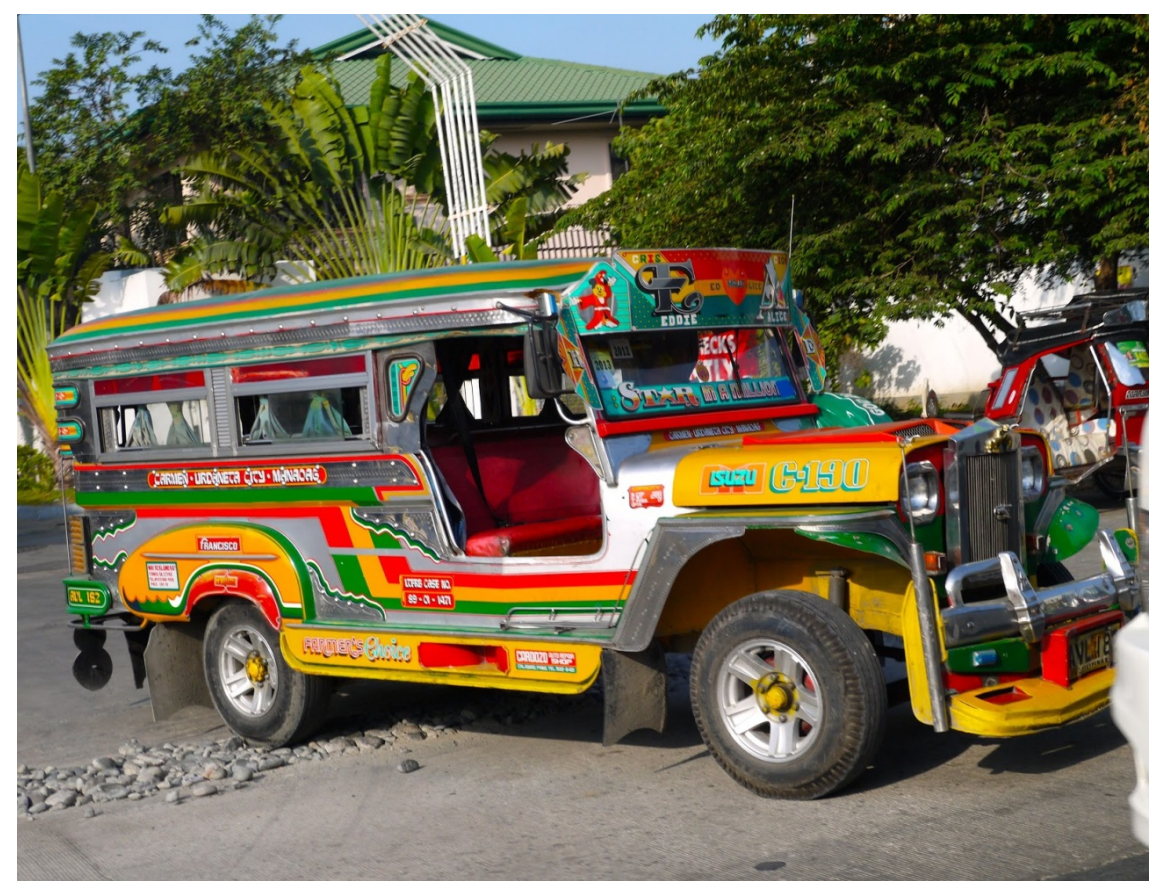

A memorable cultural icon, the jeepney is a vehicle unique to the Philippines. Inspired by the military jeeps left behind by the US Army following WWII, jeepneys are an incredibly popular form of transportation. Their affordability and relative simplicity see them used as commercial transportation vehicles or passenger vehicles due to their large size. They serve as an informal substitute for the bus system with a shifting selection of routes based on ridership demand. While the government maintains an official count based on vehicle registrations, many jeepneys are unregistered because they are easy to manufacture and acquire. Most jeepneys in Manila are diesel powered, but there are some electric models hitting the roads in greater numbers.

Figure 3. Jeepney spotlight. Source: https://quinsprogress.files.wordpress.com/2014/03/jeepney8.jpg, 2014.

- Mid-Term Initiative-Consisting of 5 years, this phase would consist of an ongoing long-term so-cial program focused on educating young adults, teenagers and children about sustainable means of transportation and encouraging a cycling culture. This would be accomplished through media, school programs and leisure activities. Metro Manila is already experiencing a congestion crisis, and demographic trends show that children and teenagers are the largest demographic population groups. As these large groups reach adulthood, the impact of their prevalent choices for transportation modes will be profoundly meaningful, either further exacerbating the current transportation sector problems to unprecedented levels or helping transition the region into more sustainable transportation networks.

- Long-Term Initiative-Consisting of 15 years, in this phase, the creation of inter-LGU non-motorized or lowimpact motorized transportation networks to facilitate short trips is proposed. Cycling, e-tricycles, and walking have been selected as the main modes of transportation for these corridors. The plan is to identify existing narrow paths that permeate the urban fabric and which already serve as non-motorized transportation pathways. These corridors display vibrant mixes of uses, and investments formalizing them into green-paths would encourage non-motorized transportation.

This three-pronged strategy aims to address the main issue at stake: the fact that a car-oriented transportation system is a system not realistically sustainable for this region. The infrastructure that is needed to support a caroriented system, based on extensive, sprawling urban development, is contradictory to the natural landscape of Metro Manila. Continuing current land development patterns is not possible due to the region's containment by water boundaries. Furthermore, the region is in constant need of natural water-absorption mechanisms to cope with frequent water accumulation events following heavy precipitation patterns of the area. In addition, the densities that Metro Manila exhibits would make it unsustainable for everyone to drive a car. The inefficiencies of the massive demand for parking that this would generate would result in a substantial burden on land that the region cannot accommodate. 


\section{Energy}

\subsection{Political Characteristics}

MERALCO, Manila's energy distributor, does not have a good relationship with the public amid several legal battles, accusations of corruption, bribes and money laundering. While MERALCO will finance and operate two brand-new 400-megawatt generators in Jurong Industrial Estate, Singapore (The Manila Times, 2014), many are wondering why they did not build these plants in the Philippines. MERALCO is profiting from denying an increase in capacity and supply, charging higher and higher prices for electricity (and much more than what is being charged in Singapore); “...something must be terribly wrong here when our biggest utility firm, which controls 60 percent of the electricity market, chooses to invest billions of pesos outside the country, which has been capital-deficient (The Manila Times, 2014).”

Strain among the different political families also affects the energy industry. In 1986, President Corazon Aquino refused to operate a large nuclear power plant that had been built in Bataan because it was constructed by the Marcos administration (Pascual, 2013). Officials have said that the reason for closing the plant was its proximity to an inactive volcano and nearby fault line. However, the International Atomic Energy Agency has inspected the plant twice, and cleared it for operation. Although these safety concerns were highlighted, "the plant was built to withstand an Earthquake of an Intensity 8 on the Richter Scale, as well as built at 18 meters above sea level to be sufficiently protected against storm damage like tidal waves and tsunamis (National Power Corporation, 2014).” The current president, Benigno Aquino III, who is the son of Corazon Aquino, has little interest in reopening the plant.

\subsection{Socio-Cultural Characteristics}

Socio-cultural characteristics can strongly affect people's energy consumption behavior. Power struc-tures (relations among people), status and social belonging can help explain certain attitudes toward consumption (Sahakian, 2011). In Metro Manila, air-conditioning use and private car ownership are very desirable as status symbols. Only the affluent can afford to have air-conditioning or a car, which are both energy intensive. Approximately $67 \%$ of people in the Philippines use energy for cooling. However, only $9 \%$ of people own air-conditioning, with the vast majority using electric fans (Ibid.). Globalization also affects social perception around energy consumption. Many Filipino return migrants especially see air-conditioning as a status symbol and put units specifically in front of their houses for people to see. In addition, following western fashion trends is important even when it comes to fall and winter clothing. There is also little use of passive or natural ventilation in built spaces because many people want western style architecture. Not only is this type of architecture not appropriate for the climate, but traditional structures are well ventilated and use natural light. While the Philippines has been greatly influenced by the American environmental movement, there has been less consumer activism (Ibid.).

\subsection{Physical and Geographical Characteristics}

The Philippines is an archipelago of 7107 islands. They are mostly mountainous with varying amounts of coastal lowlands. Metro Manila is in one of these low lying areas between Manila Bay and Laguna de Bay. The total range of elevation in the Philippines is $9700 \mathrm{ft}$. (2954 m.), while land use is primarily agricultural (41\%) and secondarily forest (25.9\%) (CIA, 2011).

The climate is tropical and maritime. There are relatively high temperatures throughout the year, high humidity, and large amounts of precipitation. The average annual temperature is approximately $80^{\circ} \mathrm{F}\left(26.6^{\circ} \mathrm{C}\right)$. The temperature fluctuates slightly. In January, the coldest month, the average temperature is around $78^{\circ} \mathrm{F}\left(25.5^{\circ} \mathrm{C}\right)$, while in the warmest month, May, the average temperature is $83^{\circ} \mathrm{F}\left(28.3^{\circ} \mathrm{C}\right)$. The monthly average for relative humidity ranges from $71 \%$ to $85 \%$ depending on the month. Rainfall is the single most important climatic factor in the Philippines. Depending on the region, the average annual rainfall could be between 38 inches $(965 \mathrm{~mm})$ or 160 inches $(4064 \mathrm{~mm})$. The Philippines is subject to monsoonal seasons. Therefore, there are two seasons: wet and dry. The wet season occurs from June to November, and the dry occurs from December to May (PAGASA, 2015).

An important geographical feature of the Philippines is that it is on the "ring of fire.” This causes issues associated with tectonic activity, including earthquakes, volcanic activity and eruptions, lahars (mud flows) and landslides. There are currently 53 active volcanoes throughout the Philippines (VD, 2015). The climate and tec- 
tonic activity of the Philippines have allowed it to build extensive hydroelectric and geothermal facilities; hence, their importance to the energy sector.

\subsection{Environmental Characteristics}

The Philippine Development Plan 2011-2016 includes an Environmental Framework. The framework includes 3 goals: improved conservation, protection and rehabilitation of natural resources; improved environmental quality for a cleaner and healthier environment, and enhanced resilience of natural systems and improved adaptive capacities of human communities to cope with environmental hazards including climate related risks. The second goal is the one that is most connected to energy use in Metro Manila; it includes the measure to "reduce air pollution in Metro Manila and other major urban centers including the promotion and use of clean fuel and indigenous resources to the fullest as sources of clean energy (PDP, 2011)."

Another measure to combat energy related environmental issues is to "develop and replicate low-cost technologies to optimize the recycling, reuse, and recovery of solid waste, including the conversion of residual organic materials into clean renewable energy (Ibid.).” Moreover, "the continually increasing demands for food, energy, and other goods, coupled with rapid development have put much stress on the natural environment resulting in the destabilization of ecosystems, destruction of natural habitats, and an alarming rate of biodiversity loss (Ibid.).”

Metro Manila contains the chief port of the Philippines, Manila Bay, which is rimmed by "heavy industries, refineries, and a power plant in Bataan, while Metro Manila is highly urbanized with light and heavy industries and factories located in various parts of the metropolis (Jacinto, 2006).” Due to rapid development and increased demand, Manila Bay and other urban esteros (estuaries) have been deemed eutrophic and unfit for human activity (PDP, 2011). Industries in the region contribute greatly to air and water pollution, which "significantly contributes to episodic hypoxic conditions in bay waters, toxic algal blooms, and suspended materials in water columns (Jacinto, 2006).” The Pasig River watershed, which divides the NCR into Northern and Southern districts, is highly inhabited and highly polluted. The dumping of wastewater and garbage from industries, households and slums contribute to this. Metro Manila produces 8,000 tons of garbage per day, and only 70\% is collected; what is not collected goes into the waterways (PDP, 2011). The cost of medical treatment and loss of income from water-borne diseases totals approximately \$141 million USD per year. Traffic congestion and unsustainable fueling methods contribute to about $80 \%$ of urban air pollution, air quality issues, and smog. As of 2011, the total suspended particulates in Metro Manila were $166 \mathrm{Mg} / \mathrm{Ncm}$, which was 84\% above the standard $90 \mathrm{Mg} / \mathrm{Ncm}$ as determined by the World Health Organization (WHO) (Paje, 2011). Due to the high rate of fossil fuel use, Metro Manila emits high rates of $\mathrm{CO}_{2}$. It is projected that in 2020, the region will emit 23.5 million metric tons from electricity alone (Ajero, 2000).

This is not accounting for any emissions from transportation, which make up the bulk of carbon emissions. The import of coal and oil for energy use also contributes significantly to environmental difficulties. The transport of coal and oil has contributed to small spills and water pollution, while the actual conversion of the minerals into energy greatly contributes to air pollution, the degradation of landscapes and ecosystems, surface and ground water pollution from combustion waste, sludge, and acid mine drainage, and the obvious and wellknown contribution to global warming. Because most energy in Metro Manila is produced from coal, there are serious implications to the environmental sustainability of the region. Potential areas of clean and sustainable energy investment include bio-energy, solar and wind energy, geothermal energy and hydropower.

\subsection{Issues}

\subsubsection{Issues with Public Distrust}

Issues of the public's distrust in the country's government and sole energy provider, MERALCO, are present and increasing. Growing distrust in the energy sector comes on the heels of the announcement of MERALCO's involvement in the development of two generators in Singapore, even though MERALCO officials have been quoted as saying Manila’s energy supply problems are due to a lack of generators (The Manila Times, 2014). There has also been involvement of the provider in lawsuits for suspected money laundering and bribery. Electricity charges (per $\mathrm{kWh}$ ) often change month to month. Some citizens are quoted as saying "This MERALCO Corporation is run by a bunch of dummies; make that rich dummies," and "These are the killers of Philippine progress, sabotaging the economy (The Philippine Star, 2015).” MERALCO has been accused of catering to 
specific people (those with high economic and/or political standing). This is a problem for low- and middle-income citizens with no money or political pull. Their needs often go ignored, adding to their troubles and disparities, and confirming the corruption that goes on in this sector. In fact, the Philippines ranked 85th out of 175 countries in the Corruption Perception Index in 2014 with a score of 38 out of 100 (0 being highly corrupt and 100 being very clean) (Transparency International, 2014). The country is improving though; it ranked 94th in 2013.

\subsubsection{Issues with Education}

The colonization of the Philippines by the United States promoted a high standard for education. Filipi-nos view education as a necessity and an avenue to social and economic mobility, and they exhaust all resources trying to provide adequate and quality education for their children. Access to education in Metro Manila largely depends on economic status. The country as a whole lags in primary education, and, as determined in 2011, it needed to increase the budget for education by over \$7.3 million USD in order to reach the target set by the Millennium Development Goals at the end of 2015 (PDP, 2011). 86.4\% of Filipinos are functionally literate, but literacy is "much higher among those in the highest income stratum and who completed high school or higher education (Ibid.).” In 2009, the number enrolled in higher education rose to 2.62 million, and access to higher education was increased through scholarships and financial aid programs (Private Education Student Financial Aid Assistance Program and the President Gloria Scholarship, for example) (Ibid.). There is much more access to educational institutions and financial help in urban centers like Metro Manila. However, education sectors, even in the NCR, face challenges with "limited participation of the industry sector in developing competency standards and curricula, the need to upgrade courses and make them internationally comparable, and the need to increase the quality and relevance of education and training programs (Ibid.).” Thus, education to provide technically trained workers at levels from technician to engineer for employment in the energy sector is currently insufficient in Metro Manila and the Philippines.

\subsubsection{Issues with Capacity}

Metro Manila has had issues with meeting capacity in the past leading to brownouts and blackouts. Brownouts could last for 10 hours or more in 1992. Demand exceeded the system's capacity by almost 50\%. This had a huge impact on industrial and commercial enterprises in Metro Manila. The loss was calculated to be approximately \$1.6 billion USD in 1992 (Mouton, 2015). While the number and frequency of outages has declined since the privatization of the sector, capacity is still a major concern. The demand for electricity increases as the population of the region grows, both from natural growth and immigration. There are also efforts to provide access to electricity for everyone. According to the Manila Observatory, the energy consumption of Metro Manila was 14,924,617 MWh in 2000 (Ajero, 2000). Using a geometric model, energy consumption was projected to be around 21, 500,000 MWh in 2020. This is a 44\% increase in consumption (Ibid.).

As of 2012, the installed capacity on the island of Luzon was 11,739 MW, and the dependable capacity was 10,824 MW. To meet current and future energy demands, there are plans to install 6819 MW between 2013 and 2020 (Petilla, 2013). Unfortunately, just over 50\% of these projects are dependent on coal, and another 37\% are dependent on natural gas. Metro Manila's reliance on coal is expected to increase significantly.

This could cause issues of national security as the region becomes more dependent upon foreign coal. The Philippines do have some coal reserves, potentially 746 million metric tons; however, a large portion is under the Philippine Sea, and extraction in general could be difficult and costly (DOE, 2008). As of 2007, imported coal made up $10 \%$ of the energy mix, and local coal less than $5 \%$.

A separate but important issue is fuel used in low-income households. In 2004, 36\% of the urban poor were using kerosene as their primary fuel type (Lumampao, 2004). They purchase kerosene because they can buy it in small amounts; however, it is expensive when purchased in this way, which means that they are paying a premium for their energy.

\subsubsection{Issues with Access}

The Philippines has a very high cost of electricity. Currently the rate is around P10.52 or \$0.22 USD per kWh, which is twice as high as some states in the US. The rates are so high that some people either can-not afford electricity or spend most of their income on it. According to MERALCO, the high rates are caused by three issues: lack of government subsidies, the high cost of supply (fossil fuels), and geo-graphic challenges (MERALCO, 
2015). In the past, MERALCO has faced issues with providing electricity access to all people. It had a lifeline subsidy scheme, which used money from other customers to provide discounted rates based on usage (Mouton, 2015). This lifeline also covered loss from people pilfering electricity, tampering with meters and not paying their bills (Ibid.). MERALCO has employed several additional methods, including putting meters on telephone poles and requesting people to turn in pilferers, that have reduced their non-technical losses (Ibid.). Even though there has been a decline in the amount of non-technical losses, the rate of electricity loss is still extremely high. This leads to many people not having access to electricity.

\subsection{Objectives}

The issues and problems faced by the energy sector in Metro Manila are extremely diverse. In an attempt to address as many different types of issues as possible, four objectives were developed:

- To encourage education about energy and consumption;

- To support energy related research;

- To help increase current energy capacity through renewable sources, and

- To address issues of access to electricity.

\subsection{Solutions}

Solutions to energy related issues were generated in relation to the four objectives. Solutions focus on promoting energy related education and job growth, identifying energy sources within the Philippines, including renewables, reducing the demand and consumption of energy, and helping disenfranchised groups gain access to electricity. In this section the full range of projects is explored with the intention of selecting a few to develop further.

\subsubsection{Research}

Many opportunities presented themselves and were considered as strategies to meet the first and second objectives. Those research opportunities included funding research on renewable energies that were possible to harness, researching and developing a system based on the Environmental Protection Agency (EPA)'s Environmental Management System (EMS), deciding whether or not to implement regulations or just have companies set their own goals should an EMS be created, establishing a home energy audit program and home energy efficiency research and information team, and researching a way to implement a public/private partnership that would consult and recommend solutions to private renewables companies. Plans to address and decrease brownouts and blackouts due to lack of maintenance, insufficient supply, and weather related damage were also considered. Related to insufficient supply, is a larger research project that addresses and evaluates the fully functional Bataan Nuclear Power Plant. The plant is not presently being operated, but is open to the public "as part of the government's information, education, and communication program on nuclear power," (which is peculiar because the government has been the main critic and negative voter on reopening the plant). Since 1986, the plant has been maintained and the reactor on preservation mode, costing about \$850,000 - \$1.1 million USD a year (NPC, 2014). The plant could potentially be operated in the near future if inspections went well and the plant was cleared to receive fuel.

The Philippine government has passed several bills and issued a number of executive orders to support research concerning energy efficiency and alternative energies. Senate Bill No. 1602 is "an act to support the research and development of new industrial processes and technologies that optimize energy efficiency and environmental performance, utilize diverse sources of energy (Reyes, 2013).” One solution would be using funds to support renewable energy research. Also, providing funds for this type of re-search sends a strong message that renewables are an important issue.

\subsubsection{Education}

"Skilled workers and firms will flock to and concentrate in cities with high quality of life, increasing productivity and contributing to the financing of further social amenities and public goods (UN-Habitat, 2015).” Many of Metro Manila's most talented and educated workers leave the Philippines to study and work abroad. The pay is higher, the conditions are better, and more opportunities are available to them overseas. Providing a way for these advanced skills to be obtained and for workers to stay in the NCR would not only benefit the energy sector, 
but the region as a whole. Therefore, education is one of the most important objectives that were selected. Because of the unprecedented need for educated workers and for individuals to understand energy consumption and use, educational programs considered included investing in training and education for technical professionals, providing a way for students to intern or participate in a work study/co-op, and providing scholarships, first and foremost, to promote equity and provide the opportunity for higher education in engineering or other appropriate fields. The hope is to select candidates of diverse socio-economic backgrounds and give them the opportunity to enter the energy field. There is also a need for consumer education about their energy habits and how they can reduce energy consumption at home. There are many different factors that influence people's consumption patterns, and it is hard to address all of them. However, if people could be approached directly and educated on energy efficiency, then not only could they have lower energy bills, but energy use during peak hours could also be reduced.

\subsubsection{Increasing Capacity}

One of the goals of the Department of Energy (DOE) is to "switch from fossil fuel-based technologies to renewable energy technologies in power generation... (DOE, 2008).” The DOE wants to increase the amount of renewable energy in the mix to 50\% by 2030 (Dancel, 2015). Different renewable and alternative energy projects considered include: solar panels and solar water heaters, wind turbines, geothermal for electricity generation, hydroelectric, hydrogen fueled cars and public transportation, bio-digesters, landfill gas collection, nuclear, natural gas, gravity powered lighting and micro-movement generators. A range of projects has been considered-from the small human scale to the large energy mix scale. The goal is to identify projects that could be implemented at different scales and with different end users in mind.

\subsubsection{Community Engagement and Access to Electricity}

As mentioned above, MERALCO already has a lifeline charge built in to pay for people using less than 100 kWh and to cover any technical and non-technical losses, including energy prefilling (MERALCO, 2015). Currently, with the privatized energy industry, people can negotiate and choose from whom they purchase their electricity (generation). The down side of the current organization of this program, though, is the exorbitant amount of electricity that needs to be consumed to qualify as what EPIRA calls a con-testable customer. A user must have "a monthly average peak demand equal to or greater than $1 \mathrm{MW}$, or after 2014, $750 \mathrm{~kW}$ (KPMG, 2013).” After 2016, market performance would be evaluated, and the threshold gradually reduced to meet household demand. The average Philippine home uses $211 \mathrm{kWh}$ (Wootton, 2013), which, if the threshold were to stay $1 \mathrm{MW}$, would power upwards of 3000 homes. In comparison, $1 \mathrm{MW}$ in the United States would power between 750 and 1000 homes, which use an average of 911 kWh a month (USEIA, 2015). In Metro Manila, it would take many years to reach the end goal of providing competition the residential demand level. However, to expedite this process, if people were able to come together as a group, they would have more leverage. This could be done at the barangay level.

\section{Water}

\subsection{Background}

The water sector in Metro Manila faces challenges not unlike those of other developing countries: unreliable access to potable water at affordable rates. This is compounded by a rapidly growing urban population, many of whom occupy informal settlements without a household, pipe borne supply. The NCR is the most densely populated region in the Philippines with $18,165.1$ persons $/ \mathrm{km}^{2}$ spread over an administrative land area of $636 \mathrm{~km}{ }^{2}$ (Asian Development Bank, 2014). This scenario describes a metropolitan population suffering from constant water insecurity.

Prior to 1997, Metro Manila’s water was supplied by the Metropolitan Waterworks and Sewerage System (MWSS), a subsidiary of the Department of Public Works and Highways. This public agency had a record of poor service and mounting levels of debt in the hundreds of millions of dollars. Until 1997, MWSS only served two-thirds of the Metro Manila population or 6.3 million persons. The remaining 3.3 million lacked connections to a pipe-borne supply and were forced to source water else-where. Privatization was viewed as a viable solution, and, in 1997, was implemented employing a con-cession model whereby the Metro Manila region was split into west and east service areas to be managed by two separate concessionaires until the year 2022. The Concession 
Agreement obligations were to treat and distribute drinking water and to manage bill collection and sanitation/ sewerage services.

\subsection{Major Problems}

\subsubsection{Non-Revenue Water}

Non-revenue water (NRW) is defined as the difference between the amount of water put into the distribution system and the amount of water billed to consumers (Espiritu, 2011). This water is lost from the system through leakage, theft or mismanagement and, therefore, not billed. Prior to privatization, NRW was 60\% but today stands at 29.4\% under Maynilad Water Services Inc. (MWSI) and approximately 11\% under Manila Water Company Inc. (MWCI). NRW can be considered as being either physical loss or apparent loss. Physical losses refer to the loss of actual water as a result of leakages in pipes. Apparent losses refer to loss of revenue exemplified by unbilled water due to data or meter errors and system flushing and theft (Ibid.). NRW contributes to the problem of only $68 \%$ of customers in the west region receiving a 24 hour supply. This gap between demand and supply results in water being purchased from illegal vendors at exorbitant prices or stolen from network lines via unauthorized connections. NRW detection is important to mitigate the reduction in water allocations that occur as a result of water shortages that arise due to environmental issues.

\subsubsection{Rapid Urbanization}

Rapid urbanization is placing significant pressure on Metro Manila's water infrastructure. Since 1997, MWCI has made steady improvements and remained profitable while MWSI has consistently lagged behind. In 2010, however, MWSS approved a 15-year Concession Agreement term extension to MWSI to continue operations (Maynilad Water Services Inc., 2010). At present, an estimated 3.3 million people in Metro Manila’s western region live without a reliable 24-hour water supply. With the over three-quarters of the national population projected to live in urban areas by 2030, the challenges of urbanization will undoubtedly be amplified in this region as infrastructure struggles to keep pace with the projected increase in inhabitants.

\subsubsection{Affordability}

To ensure that operations can continue sustainably, water service providers must charge tariffs allowing them to recover their investments, which include government-regulated profits. The cost of water is heavily subsidized with the poorest customers paying approximately $24 \%$ of the cost of connection. The Philippines has the significant intra-urban inequality and associated high levels of poverty (Asian Development Bank, 2014). This means that its most vulnerable inhabitants are not truly able to afford water or other basic urban services. Furthermore, water service providers are unable to maintain or increase service coverage without a tariff-paying customer base from which to recoup their costs.

\subsubsection{Potable Water in Illegal Settlements}

MWSS, Maynilad, and Manila Water Company (MWCI) often refuse to extend water infrastructure to illegal settlements due to their illicit nature as well as their impermanency. They are also afraid that squatters will steal water from pipes. Additionally, because these illegal settlements are built in areas such as flood plains, railroad track rights of way, and garbage dumps, there is often inadequate space for pipes. Furthermore, workers have a difficult time being able to reach these areas because they are built in dangerous spaces. As a result, the poorest people in society must buy their water from vendors and often end up paying 10 to 25 times more than the wealthiest members of society (Argo et al., 2011).

\subsubsection{Pollution of Waterways}

Many of the waterways in Manila have been considered biologically dead due to the amount of trash and pollution in them (The Philippine Star, 2004), but cleaning up the waterways would have many benefits, including helping to refurbish the water table, increasing general health, allowing for better flood drainage during natural disasters, as well as the economic benefits that could come with increased tourism when the environment is more aesthetically appealing. Most rivers in Metro Manila already have their riverbanks cemented to protect the buildings that are built next to them, although the overwhelming majority of these buildings have their sewer systems drain right into the rivers. This is an accepted practice in the Philippines. 


\subsubsection{Flooding/Natural Disasters}

There are six to seven typhoons every year in the Metro Manila, which cause major flooding. Destructive earthquakes, and tsunamis are natural disasters Metro Manila is also prone to, and they can cause extensive amounts of flooding (CIA, 2015). The effect of this flooding is compounded by the extreme pollution in the city. This includes trash blocking drainage systems as well as clogging waterways. Additionally, illegal settlements along flood plains and waterways reduce the capability for drainage during floods (Environment and Natural Disasters, n. d.).

\subsection{Solutions}

\subsubsection{Institutional Capacity Strengthening}

The SUKI Program, developed in 2005, is a program created by MWCI to assist “mom and pop" business operations in becoming established vendors, while assisting water service providers in enhancing service delivery. It is a mutually beneficial program, which serves as an economic development tool while improving the goals of the service provider (Asian Development Bank, 2014). Since MWSI changed ownership in 2007, new management has orchestrated a series of internal restructurings and capital investments in order to reduce NRW levels, boost customer service, and make the company profitable once again. \$760 million USD were invested in capital expenditure projects between 2008 and 2012 aimed at replacing and rehabilitating deteriorated networks and lines. The introduction of District Metered Areas (DMAs), similarly employed by MWCI, allowed for the subdivision and localized management of network rather than a highly centralized, bureaucratic approach (Espiritu, 2011). MWSI formed partnerships with labor unions, which not only achieved technical goals, but helped improve management and employee relations as well. These partnerships specifically helped to resolve leak detection issues, worker compensation and benefits, employees' rights and legal services and workers' security at job sites (Ibid.).

It is recommended that the above mentioned programs, currently executed by both concessionaires, be enhanced and expanded to help manage existing and future infrastructure demands, service delivery and customer satisfaction challenges. Furthermore, independent audits and evaluations should be conducted to ensure compliance with MWSS Regulatory Office obligations and harmonization with regional planning and growth management efforts.

\subsubsection{Water for the Community Program Enhancement}

“Tubig Para Sa Barangay” (TPSB), or Water for Low Income Communities, is an initiative developed by MWCI that has successfully increased water access for poor and low income communities. This was achieved by removing a critical barrier to the connection application process-proof of land ownership (Asian Development Bank, 2014). A successful launch and adoption of the land tenure mobile application proposed by the poverty alleviation team earlier would see many more persons receiving household connections. Another crucial element of the TPSB Program is flexible financing plans for connection with the customers opting to pay either an upfront fee of \$33 USD, or pay the fee in installments over a period of 36 months. This works out to less than \$1 USD per month (Ibid.).

MWCI was able to access a grant through the Global Partnership on Output-Based Aid (GPOBA) pro-gram of the World Bank, thereby subsidizing the cost of connection (\$100 USD per connection). The value of this grant was \$2.8 million USD and impacted the lives of 1.7 million people. Utilizing this impact as a benchmark for the cost providing affordable 24-hour access, it can be estimated that \$6.4 mil-lion USD (adjusted for inflation) would be needed to provide reliable access to approximately 3.3 million underserved customers in Metro Manila's western region. Further development of urban centers within or bordering the NCR should promote denser development using green building practices where feasible. Such an approach would reduce demand on capital investments in water network infrastructure for future development in this rapidly developing region.

\subsubsection{Waterway Rehabilitation}

To combat the pollution of waterways, steps should be taken to implement the Clean Water Act, RA 9275 (Environment and Natural Disasters, n. d.). This would be accomplished through the organization KapitBisig Para saIlog Pasig Project (KBPIP). KBPIP, along with multiple donors and participants, including MWSS, Manila Water Company, Maynilad, IBM, Citibank, the Department of Tourism, SC Johnson, McDonalds, Unilever, and 
almost 200 other local and international partners, has already done an extremely efficient job of improving the quality of the Pasig River (KapitBisig Para saIlog Pasig, n. d.). This program should be continued for the Pasig River, as well as replicated in other area rivers, be-ginning with the San Juan, Parañaque, and Marilao Rivers (Ibid.).

\subsubsection{Stabilization Ponds}

Stabilization pond technology or "lagoons" is a natural method for wastewater treatment that requires a considerable amount of space and is, therefore, not generally suitable for urban areas. It can treat municipal wastewater, industrial effluent or polluted storm water. After treatment, the effluent may be returned to the environment as fertilizer and irrigation water. In this case, the Marilao River has potential for implementation of this measure because it has sufficient space in the area. These areas can be used to build stabilization ponds to treat polluted water from Metro Manila.

\subsubsection{Constructed Wetlands}

Constructed wetlands are treatment systems that use natural processes involving wetland vegetation, soils and their associated microbial assemblages to improve water quality. In this case, the river best suited to support a constructed wetland is the Parañaque River because of its close proximity to the mangrove swamp and estuary.

\subsubsection{Polluter Pays Program for Industrial Waste in Rivers}

Another component of pollution for the rivers in Metro Manila is industrial waste. This is especially prevalent in the Marilao River (Environment and Natural Disasters, n. d.). The best way to combat this problem is source reduction. MWSS should work directly with companies to reduce the amount of toxins included in its operations before they are released into the environment. This reduction would be accomplished through an education program on safer chemical alternatives to be used in respective industries. A database would be consolidated for consultation on what exactly these chemicals would be (Pollution Prevention (P2), n. d.).

To give this effort strength, a Polluter Pays Program should be established to fine factories that pollute waterways. The criteria for what exactly constitutes "polluting substances" would be established by the employment of the methods KBPIP uses in its cleaning procedures and testing of river waters. This initiative would specifically focus on industrial waste due to the fact that toxic chemical pollution takes place at such a high level and begets extreme hazards for the population by threatening the water supply. This would first be implemented with industries polluting the Marilao River, and, if successful after a one year trial period, would be extended further. Factory facilities would be audited to see to what extent they are responsible for polluting. The fee would then be proportional to the amount of toxins emitted and the price of the cost of cleaning these substances from the river. This initiative would be established on the legal premise that contamination of the waterways is potentially harmful to the quality of the product of Maynilad and the Manila Water Company, thereby costing them more for water treatment. MWSS would be in charge of collecting the fee. This office would then use the fee income to provide grants to be distributed to organizations working to clean the rivers. Since Maynilad and the Manila Water Company have both worked closely with KBPIP, they are likely recipients, but grants will not be limited to these organizations alone.

\subsubsection{Natural Disaster Resilience Plan}

To alleviate the destruction posed by future natural disasters on the water infrastructure, regular audits and inspections of water facilities should take place, being more frequent during the period right before the rainy season to prepare for future developments. Building codes should be inspected to make sure they're up to date, and should be evaluated to make sure that best practices are being used (Environment and Natural Disasters, n. d.).

Hazard maps for flooding should be created to establish a plan for areas that are at a high risk for flooding and for areas that are critical to drainage. The latter area should be zoned so that structures that would block this drainage are not built. Funding should be provided to develop better data that can be used in GIS systems to map out these specific areas (Ibid.). This would be carried out as part of the flood management master plan for Metro Manila that was approved in July 2012.

A "floodway" is the channel of a river or other watercourse and the adjacent land areas that must be reserved in order to discharge the base flood without cumulatively increasing the water surface elevation more than a designated height (FEMA, 2015). Communities must regulate development in these floodways to ensure that there are no increases in upstream flood elevations. 
In this case, the San Juan River has the potential to absorb the water when it meets the flood. The main cause of flooding in a number of barangays in the city is the heavily silted San Juan River where most of the garbage flow from upstream Quezon City travels down to San Juan, Mandaluyong, and Manila eventually ending up in the Pasig River. A certain amount of trash and garbage from the last three cities also poses a problem.

San Juan City actively participates in the MMDA Flood Control Bayanihan Zone Alliances Zones 6 and 7 that help conduct clean-up operations along Maytunas and Ermitanyo Creeks and monitor the flood-control program of the MMDA, San Juan City and Mandaluyong City (San Juan River-from Quezon City to Mandaluyong, 2012).

Tree planting would help alleviate a variety of problems taking place in Metro Manila today. Planting native trees, which are naturally more typhoon resistant, would aid in reducing the damage that occurs due to uprooted trees and erosion. Additionally, trees would help with air quality and aid in refurbishing the depleted water table. The restoration of the water table would lessen shortages that arise due to a lack of rain, or because of weather phenomena such as El Niño (Ranada, 2015). To accomplish this task, KBPIP should partner with school children to plant the trees. The act of planting a tree would help people become more personally invested in caring for the environment by creating something with their own hands, especially if this begins at a young age. Further care for these trees could also be done by schoolchildren to continue this sense of investment. The National Greening Project is currently working on a program to plant trees, but this should be extended with the involvement of children in schools, as well as with the use of more native plants (Ibid).

Between 1970 and 2013, Metro Manila experienced three super typhoons named Sening (Joan), Titang (Kate) and Yoling (Patsy). In 1947, one wreaked havoc in the City of Manila, its suburban areas and nearby provinces, in terms of flooding and damage to property. However, it would not be until November 1991 that Typhoon Uring would claim more than 5,000 lives (Ado, 2009).

A protection area would mitigate destruction from the storms before they take place. This project would use native plants to aid in the recovery of the land and create a mangrove forest in the Parañaque River area and at the border between Manila Bay and the Metro Manila region.

\section{Sewage and Sanitation}

\subsection{Background}

Metro Manila is arguably the most densely populated city in the world, and like many other densely populated areas with insufficient regulation, there are associated consequences. In this megacity, a significant amount of pollution is created through industrial waste, automobile emissions and open dumpsites (The Philippines Country Study, 2013). Improper waste disposal methods also play a critical role in pollution in the region, and lead to abysmal sanitary conditions.

Metro Manila "generates about 7000 metric tons of solid waste daily, with a daily waste generation of $0.66 \mathrm{~kg}$ per capita per day (Bernardo, 2008; Storey, 2012).” Moreover, Emy Aguinaldo, the executive director of the National Solid Waste Management Commission_as quoted in the Philippine Daily Inquirer-asserts a single resident of Metro Manila produces a quantity of daily waste around 130\% higher than the global average of $0.3 \mathrm{~kg}$ per person per day (Alave, 2011). Considering this, the amount of waste generated is beyond the capacity of what Metro Manila can manage to dispose of efficiently. Only 85\% of the waste is collected, while the remaining $15 \%$ is typically left on the streets or dumped in waterways (Bernardo, 2008). This has resulted in several rivers in the region becoming biologically dead-most notably the Pasig River.

One of the main issues with waste management in Metro Manila is the shared perspective of who is held accountable. About $69 \%$ of the population believes the government is responsible for garbage collection and disposal (Ibid.). This belief has proven to be problematic for the region. Moreover, with the closure of two dumping sites, Carmona Landfill and San Mateo, in the late 1990s and early 2000s (Storey, 2012), in conjunction with inadequate capacity at other sites, a serious insufficiency in adequate dumping sites has also contributed significantly to the waste disposal problems throughout Metro Manila (Bernardo, 2008).

One of the most notable tragedies to ever happen in Metro Manila was the collapse of Payatas Mountain, a gigantic garbage dump, on 10 July 2000. Around 330 people-men, women, and children who worked and lived on the mountain — were buried alive as a result of slope failure (Gaillard and Cadag, 2009; Almendral, 2014). A total of 58 persons were rescued, 278 bodies were recovered, and about 655 families were displaced as a result of the waste avalanche (Merry, Kavazanjian, \& Fritz, 2005). Prior to the collapse, Payatas was an open dumping 
site where scavengers would wait daily for the arrival of the dump trucks in order to rummage through the loads in search of reusable and sellable items.

The downfall of Payatas not only accentuated the need to cease open dumping, but also made clear the need to implement and follow through with regulations concerning the management of waste. Within that same year, the Philippine government shut the Payatas open dumpsite (but later reopened it due to the income that scavenging through the trash provided for the villagers, and due to not having other alternatives for the trash) and passed the Ecological Solid Waste Management Act-also referred to as RA 9003. The establishment of RA 9003 has resulted in the creation of solid waste management bodies at the national, provincial, and municipal levels of government (Storey, 2012). RA 9003 seeks to protect the health of the public and the environment by encouraging waste minimization, waste segregation and participation in the management of solid waste on the private sector and barangay (village) levels. Although the Philippine government has established RA 9003, the perennial problem of the management of solid waste in Metro Manila is the lack of regulation. Currently, the law specifies that half of all waste be diverted, and within in every few years, the waste diversion will slightly rise until reaching 93\% (Wrona, 2014; Almendral, 2014). According to an analysis by the Asian Development Bank (as quoted in the Philippine Daily Inquirer), "the 93\% is the portion of an average Filipino's garbage that can be composted or recycled (Almendral, 2014).” Unfortunately, this law, similar to other laws in the Philippines, has not been implemented. Enforcing existing laws and regulations, however, are critical in helping Manila become a zero-waste city.

\subsection{Current Conditions in Manila}

\subsubsection{Sanitation}

Inadequate sanitation threatens the welfare of Filipinos and essentially the Philippine economy. In Metro Manila, many of the health problems experienced by residents are linked to poor sanitation. In 2004, it was reported that, "twenty-five Filipinos die of diarrhea every day and sanitation-related epidemics have broken out over the last few years in low income communities (Philippines Sanitation Sourcebook, 2004).” The outbreak of sanitationrelated epidemics is likely the result of waste being dumped into waterways such as the Pasig River-as was previously mentioned.

At one point in history, the Pasig River, passing through the central urban section of Metro Manila, was a major waterway of historic, social, cultural, and commercial significance to the Philippines. Population growth, urbanization, and industrial activities with the concomitant results of indiscriminate discharge of untreated municipal and industrial wastewater and solid waste exceeding the river system's absorptive capacity had made the Pasig River seriously polluted (Asian Development Bank, 2012). This means that because the Pasig River passes through an important part of the city, its pollution affected many parts of Metro Manila. According to the United Nations Development Program (UNDP, 2006), 70\% of pollution in the Pasig River was due to human waste, and, according to a 2003 report, 150 tons of domestic waste and 75 tons of industrial waste had been dumped in the Pasig River (Water Environment Partnership in Asia, n. d.). This type of pollution has had significant, and at times detrimental, effects on the sustainability of the Philippine environment and the public health of the citizens.

As waste decomposes, hazardous substances and toxins can leak into the ground sullying local water supplies (Elloso, 2013). Clean water-including local water supplies-is not only critical to human life, but it is also vital to plants, animals and aquatic life that depend on clean, sanitized water. Inadequate sanitation can also affect the ability to use rivers, bays and other bodies of water for the use of transporting and trading goods, thus limiting the economic growth of a country even further. The Philippines Environment Monitor reported in 2007 that a significant amount of the surface water in most large urban centers consists of rivers that pose a public health risk (class C standard or below) (Asian Development Bank, 2013). Additionally, the "coliform bacteria found in all rivers in Manila exceeded Department of Environment and Natural Resources (DENR) standards, in some cases by several orders of magnitude (Ibid.).” The presence of coliform bacteria in water indicates fecal contamination. Coliform can cause diarrhea, which has been known to be deadly in the Philippines. In 2004, the Philippines Clean Water Act (RA 9275) was passed. This act provides a comprehensive and integrated approach to addressing the intertwined issues related to the quality of water, sanitation and pollution. RA 9275 refutes the previous notions and former policies that sanitation is the responsibility of individual households (Philippines Sanitation Sourcebook, 2004). By changing sanitation policies, the government now has a shared responsibility in ensuring and protecting water quality, sanitation, and the control and prevention of pollution. Guaranteeing 
the adequate provision of municipal sanitation systems would be most achievable when looked at as a group effort. Both individual households, or the Filipino public, and the LGU's must work together in order to solve their sanitation problems. RA 9275 will supplement other laws and policies in the Philippines such as, but not limited to, the Sanitation Code (PD 856) of the Metropolitan Waterworks and Sewerage System (MWSS).

\subsubsection{Solid Waste}

The composition of waste generated in Metro Manila is highly biodegradable. In fact, around 50\% of waste is decomposable matter such as kitchen and food waste (Storey, 2012). The other types of waste include PET bottles, metals, papers, wood, animal carcasses, cans, boxes/cartons, glass bottles, yard and garden wastes, and cellophane and plastics (Bernardo, 2008). This illustrates that enforced composting, recycling, and waste segregation methods would be viable solutions for Metro Manila's waste management problems.

As the population continues to grow rapidly, so will the amount of waste generated. This heightens the importance of reinforcing existing legislation. Not only are collection services becoming less proficient, but due to growing public opposition, distrust, and malapropos siting and management, treatment and disposal facilities are facing closure (Ibid.). Therefore, the importance of enforcing regulation on both the government and community levels in order to alleviate the waste problems seen in the NCR cannot be stressed enough.

\subsection{Proposed Projects}

\subsubsection{Environmental Education (EE) Program}

An EE program is a hands-on opportunity to provide children and adults with the tools and skills needed to care for and investigate their own environments. Participants would also learn how to make informed and intelligent decisions regarding the methods to take care of their environment(s). Additionally, an EE program teaches children and adults to take shared responsibility in the condition of their environs. In Metro Manila, there is a shared perspective that the government is responsible for the welfare of the environment. Because of this, many residents are not doing their part in mitigating the issues surrounding the management of solid waste in their communities.

EE programs would be implemented in regular classroom curricula for primary and secondary school children. Previous studies have indicated that social change becomes more evident and widely accepted when children are the target group - children have influence over the immediate and/or direct environments. Workshops on EE training would be offered to local leaders and educators, as well as to residents. This would be in conjunction with an awareness program. Local advocates, in conjunction with the government, would be responsible for the construction, implementation and follow through of any EE program.

\subsubsection{Mandatory Segregation and Waste Disposal (MSWD) Program}

A MSWD program is a mandated educational program in which children and adults learn the proper ways to separate their solid waste into recyclable and non-recyclable categories. This program could be implemented with any EE program, but differs from environmental education because it would focus solely on the issues surrounding solid waste, the lack of its management in Metro Manila, and the importance of separating and disposing of waste.

Metro Manila produces an average of 8,700 tons of garbage daily of which over 2,000 tons are biodegradable household waste. There is a need to learn how garbage in Metro Manila can be recycled and transformed into reusable items. Each household would be responsible for separating its trash and waste. It would also be given recycling bins that would be picked up on a bi-weekly basis. Furthermore, this program would be useful in lowering the unemployment rate as it would provide employment opportunities.

Barangay (i.e., local) governments would be held responsible for the construction, implementation, and follow through of any MS program. However, everyone is a part of the problem; thus, everyone should be part of the solution. Consequently, residents would be fined for:

- Any and all improper recycling and/or waste disposal methods;

- Neglecting to have bins ready for pick up at scheduled times, and

- Failure to participate in the MS program.

Section 32 of RA 9003 provides that each barangay or cluster of barangays should establish and operate material recovery facilities (MRF's) for the final sorting, segregation, composting and recycling of wastes, and that the resulting residual wastes should be transferred to a long term storage or disposal facility or sanitary landfill. 


\subsubsection{Recycling + Waste Management Program (Zero Waste Program)}

A zero waste program does not mean there would be no waste to be collected or disposed of because everything would be recycled. Rather, it would be a holistic approach of handling solid waste materials where any waste materials that are still useful would not be allowed to go to waste.

\subsubsection{Sustainability Project}

In the case of Metro Manila, sustainability projects would be employed to conserve the natural resources of local communities. Sustainability projects include both urban farming and composting.

\section{Finance}

\subsection{Role of the Finance Team}

For this plan, the role of the finance team was to research and examine the foreign and domestic sources of funding in the Philippines, and determine how much funding is potentially available for the proposed projects in Metro Manila. These sources include foreign aid, foreign direct investment and the government budget, comprised of tax revenue and Gross Domestic Product (GDP). Each sector team (poverty alleviation, industry, transportation, water, energy, sewage and solid waste) provided its list of prioritized projects, and how much funding the projects would require over the 5-year period of the environmental plan for Metro Manila. The finance team critically examined the three sources of funding, and compiled estimates of the money available for each sector and project.

\subsection{The Problem}

Although the Philippines is now one of the fastest growing economies in Southeast Asia, it continues to face many obstacles to development, and to eradicating the significant issues of poverty, sewage, corrupt governance, damage done by natural disasters, and more, as explained thoroughly by each of the preceding sectoral teams. There has been strong economic growth over the past decade, and gross domestic product continues to increase each year. However, the finance sector of the country continues to falter, due to a "perception of heightened instability, low investor confidence, and inefficiencies arising out of structural impediments" (Asian Development Bank, 2015). Furthermore, unemployment and underemployment continue to be major issues, as well as overseas and vulnerable employment, and the stagnant performance of the industry sector. Therefore, in the Philippine Development Plan 2011-2016, the development goals outlined include high sustained and inclusive growth, an increase in professional opportunities and higher quality of life for the citizens, the development of worldclass transportation (for both people and goods), environmentally-friendly use of the land, socially-responsible property rights and effective and transparent governance (NEDA, 2011). Clearly, government officials in Metro Manila know what its problems are, and are making strides to solve them. Thus, the Government of the Philippines has specified certain amounts of its budget to go towards each of these priorities. The donor countries and foreign investors, too, provide money for specific sectors. Each of the sources was analyzed in order to estimate the funds.

\subsection{The Process}

The process that the finance team followed in determining the amount of available funding for each sector is detailed below, broken into the previously mentioned three sources of financing: foreign direct investment, foreign aid and the government budget.

\subsubsection{Investment}

Foreign direct investment is considered here as the direct investment of private overseas companies into private companies in the Philippines, usually to produce products. However, private companies also often manage many of the social services and development enterprises of the country in which they are investing. This is not done purely for the good of the country, but rather, these investments are intended to generate a profit for the investors. Taking this into consideration, the finance team then researched the countries and companies investing the most in the Philippines. 


\subsubsection{Foreign Aid}

Foreign aid is official assistance given to developing and transitional countries by the governments of high-income countries. This assistance comes in different forms such as bilateral aid from individual countries, including grants, which do not have to be paid back; concessional loans, which must be paid back, but at low interest rates, and over long periods of time. It also includes money given by developed countries to multilateral institutions, e.g., World Bank, the various agencies of the United Nations, and regional development banks such as the Asian Development Bank (ADB). Although this assistance is quite different from foreign direct investment, it is still intended to benefit the donor countries. As noted by the World Bank, "donor countries are motivated by the desire to support their political allies and trade partners, to expand the markets for their exports, and to reduce poverty and military conflicts threatening international security (World Bank, 2004).” Furthermore, most of this assistance is "tied," meaning that the country receiving it is then required to purchase goods and services from the donor country in return. Based on these assumptions regarding foreign aid, the finance team identified the major donors to the Philippines, and, thus, Metro Manila.

\subsubsection{The Government Budget}

The government budget is comprised of both tax revenue and Gross Domestic Product (GDP). Therefore, in approaching the amount of funds available from this source, the finance team analyzed the proposed budget report by the Department of Budget and Management for 2016 for all of the Philippines. The team looked into how much money is available totally, and then broke it down into how much is available for each sector from which Metro Manila would draw. Again, these amounts will be detailed shortly.

\subsection{Analysis of the Sources of Funding}

\subsubsection{Government Income}

To analyze government income from 2016 to 2020, the finance team looked at GDP data and tax revenue records to estimate government income for the NCR.

\section{1) Gross Domestic Product}

The Gross Domestic Product of the Philippines has grown significantly from 2010 to 2014, with the value rising from \$199.59 billion USD to \$284.58 USD billion. The team estimated GDP from 2016 to 2020 (see Table 1) by using a straight line projection of the GDP growth rate from the previous five years, which was $7 \%$ annually.

\section{2) Government Tax Revenue}

From statistical data of the Bureau of Internal Revenue (BIR) (2015), a remarkable 86.5\% of total tax revenue is collected from Metro Manila. The revenue has increased on average by $12 \%$ annually. Using this increase in a straight line projection, the tax revenues from 2016 to 2020 for both the Philippines and Metro Manila are estimated in Table 2.

Table 1. Estimate of GDP of the Philippines from 2016 to 2020.

\begin{tabular}{lc}
\hline Year & GDP \$ (Billion USD/Year) \\
\hline 2016 & 321.39 \\
2017 & 340.48 \\
2018 & 359.57 \\
2019 & 378.65 \\
2020 & 397.74 \\
\hline
\end{tabular}

Source: Finance team.

Table 2. Estimate of tax revenue 2016 to 2020 (Million USD).

\begin{tabular}{cccccc}
\hline Area & $\mathbf{2 0 1 6}$ & $\mathbf{2 0 1 7}$ & $\mathbf{2 0 1 8}$ & $\mathbf{2 0 1 9}$ & $\mathbf{2 0 2 0}$ \\
\hline Philippines & $\$ 34,169.55$ & $\$ 38,269.90$ & $\$ 42,862.29$ & $\$ 48,005.76$ & $\$ 53,766.46$ \\
M. Manila & $\$ 29,556.66$ & $\$ 33,103.46$ & $\$ 37,075.88$ & $\$ 41,524.99$ \\
\hline
\end{tabular}

Source: Finance team. 
From the above analysis, it can be observed that the Metro Manila government receives more income each year due to increases in GDP and tax revenue. Its share of the national total is assumed to remain constant at the historical figure of $86.5 \%$.

\section{3) Government Budget}

According to the Department of Budget and Management (DBM), for 2016, the Government of the Philippines will have a total budget of $\$ 64.04$ billion USD. The government will spend 36.8\% of the budget for social services, $27.6 \%$ for economic services, and $14.0 \%$ for debt burden. However, DBM estimates that debt payments will decrease more each year, so there will be additional available funding in the budget for both social and economic services (DBM, 2015).

The budget is divided into two parts (see Table 3): the department budgets, which are provided to 34 government agencies and the special purpose fund (SPF), which is an additional budget from other resources for specific purposes. The finance team selected the departments that related to this environmental plan for Metro Manila, and estimated an amount of government support for 2016to 2020, which is shown in Table 4.

\subsubsection{Foreign Aid}

The countries and multilateral institutions currently giving the most funding to the Philippines are Japan, China, the World Bank, the Asian Development Bank, the United States and Korea (Troilo, 2011). Of importance, however, is that there are certain sectors in which these countries and institutions have particular interest, due mostly to concerns with economic development, and maintaining peace and stability in the region.

Table 3. Government budget (USD).

\begin{tabular}{lll}
\hline Budget Type & 2016 Budget & Percent \\
\hline Department Budgets & $\$ 1,696,173,154$ & $56.50 \%$ \\
Special Purpose Fund (SPF) & $\$ 1,305,626,846$ & $43.50 \%$ \\
Total & $\$ \mathbf{3 , 0 0 1 , 8 0 0 , 0 0 0}$ & $\mathbf{1 0 0 \%}$ \\
\hline
\end{tabular}

Source: Department of Budget and Management, 2015.

Table 4. The government support budget estimate (Million USD).

\begin{tabular}{|c|c|c|c|c|c|}
\hline Department & 2016 & 2017 & 2018 & 2019 & 2020 \\
\hline Department of Education & 7988 & 8148 & 8311 & 8477 & 8646 \\
\hline Department of Energy & 34 & 35 & 35 & 36 & 37 \\
\hline Department of Environment and Natural Resources & 429 & 438 & 447 & 456 & 465 \\
\hline Department of Health & 2308 & 2354 & 2401 & 2449 & 2498 \\
\hline Department of the Interior and Local Government & 2312 & 2359 & 2406 & 2454 & 2503 \\
\hline Department of Labor and Employment & 291 & 297 & 303 & 309 & 315 \\
\hline Department of Public Works and Highways & 7218 & 7,362 & 7509 & 7659 & 7813 \\
\hline Department of Science and Technology & 335 & 341 & 348 & 355 & 362 \\
\hline Department of Social Welfare and Development & 1921 & 1959 & 1998 & 2038 & 2079 \\
\hline Department of Tourism & 67 & 68 & 69 & 71 & 72 \\
\hline Department of Trade and Industry & 75 & 77 & 78 & 80 & 81 \\
\hline Department of Transportation and Communications & 832 & 848 & 865 & 883 & 900 \\
\hline Total & $\begin{array}{c}\text { 23,809 } \\
\text { Million }\end{array}$ & $\begin{array}{c}\text { 24,285 } \\
\text { Million }\end{array}$ & $\begin{array}{c}24,771 \\
\text { Million }\end{array}$ & $\begin{array}{l}\text { 25,267 } \\
\text { Million }\end{array}$ & $\begin{array}{c}25,772 \\
\text { Million }\end{array}$ \\
\hline
\end{tabular}

Source: Department of Budget and Management, 2015. 


\section{1) Japan}

Japan, the country giving the most to the Philippines, offers foreign assistance in all three forms: bilateral grants, bilateral loans (ODA loans) and contributions to multilateral organizations. It works through the Japan International Cooperation Agency (JICA), which gave approximately \$2.66 billion USD total to the Philippines in 2011. In that year, \$535 million USD went to transportation improvement plans such as the Road Upgrading and Preservation Project. However, as of late, with the high number of natural disasters in the Philippines, much of JICA assistance is going to disaster relief. In 2012, it still gave \$432.52 million USD in low-interest loans for the Capacity Enhancement of Mass Transit System in Metro Manila Project (JICA, n. d.). Thus, the finance team estimates that as JICA is giving such a large amount, and is particularly interested in the improvement of transportation in the Philippines, that there would be more than enough to supplement the funding coming from foreign direct investment and the government budget for the projects the transportation team is proposing. The amount the transportation team estimates for its projects is \$430 million USD.

\section{2) China}

China is also one of the major donors to the Philippines, although it has recently lowered that amount. Along with Japan, it provides significant assistance for disaster relief. In other countries, China's priorities are agriculture, industry and education. However, for the Philippines, it is more interested in funding transportation improvement projects. In 2011, it was estimated that China distributed \$314 million USD for the Main Line South Railway Project, which would connect Metro Manila to the other areas of Southern Luzon, and \$630 million USD for the Metro Manila Skyway Project (Dorell, 2013). Thus, although they are not currently giving as much as they once were, (the current total amount is unknown), transportation is still clearly a sector in which it has an interest. Consequently, the finance team estimated that China continues to give about \$300 million annually in foreign aid for transportation.

\section{3) World Bank}

Reported as recently as August of 2015, the World Bank is currently giving \$2.8 billion USD in foreign aid to the Philippines. One of their largest projects is the Pantawid Pamilyang Pilipino Program, which aims to reduce poverty, increase the accessibility of early education and provide healthcare for mothers. The bank increased its assistance from \$50 million USD to \$405 million USD in 2011. The World Bank clearly has an interest in providing funding for the poverty reduction sector, and it can be estimated, then, that there would surely be enough funding for the VSLAs program the poverty alleviation team is proposing. However, one must recognize that much of this funding is going to projects in the southern island of Mindanao rather than Luzon where Metro Manila is located. Nevertheless, the finance team estimates that there would still be at least \$100 million USD available for poverty alleviation in Metro Manila (World Bank, 2015). Also, in 2011, the World Bank provided a grant of \$1.5 million USD to Manila for its Flood Control Master Plan, so one can assume that the bank is continuing to support the prevention of destructive floods, which helps the water team in financing their projects (World Bank, 2011).

\section{4) Asian Development Bank}

As the Philippines is its host country, the Asian Development Bank (ADB) also gives it a significant amount of foreign aid; $\$ 11.70$ billion USD (Asian Development Bank, 2011). While ADB has contributed in the past to transportation improvement projects (\$200 million USD for investments in energy-efficient electric vehicles in the NCR in 2011), and continues to provide assistance for disaster relief, recently it has taken an interest in developing competitive labor markets in the Philippines. It recently approved giving \$350 million USD for this purpose. The project includes a "youth employment program, a program to develop skills and services in the tourism industry, and longer-term labor policy reforms (Ibid.).” Therefore, this, in addition to the funding provided for the industry sector by the government budget and foreign direct investment, is certainly enough to cover the costs of their proposed projects. Also, it has recently been proposed to loan the Philippines \$100 million USD for the Metro Manila Water and Sanitation Development Project (Asian Development Bank, 2015). Thus, assuming that this passes, the water sector then has an additional \$100 million USD for its projects.

\section{5) The United States}

The United States gives to the Philippines through the United States Agency for International Development (USAID), and it committed to providing \$197 million USD in 2012. The priority sectors for funding are disaster relief, maintaining peace and security in Mindanao, and poverty alleviation. In 2014, USAID provided \$13.7 million USD in social services and education (USAID, 2015). However, one would assume that much of this goes to Mindanao. Therefore, while a portion of this funding most likely goes to Metro Manila, the finance team cannot determine how much. 


\section{6) Korea}

As an important trading partner of the Philippines, South Korea is now giving aid to the country as well. Generally, its priorities are health, infrastructure, environment, disaster relief and transportation. As for the years to come, Korea plans to continue to increase this amount. "As the Korean Government recently joined the Development Assistance Committee of the OECD and continues to support the achievement of the Millennium Development Goals by 2015, Korea will significantly enhance and increase its grant aid cooperation programs in the Philippines (Jinoh, n. d.).” It has recently proposed to provide \$100 million USD through its development assistance agency, KOICA, in the form of a loan for the South Manila Commuter Rail Project, which is useful to the transportation team (Ibid.).

\subsubsection{Private Investment}

The private sector plays a large role in economic development in the Philippines. Many public services are run by private companies. The government highly encourages foreign investment, as it creates more employment opportunities, by having established a free-trade area and providing sufficient infrastructure services (Bangko Sentral ng Pilipinas, 2015). The country also has much potential due to its location (as it is considered to be a gateway to Asia), workers who speak English welland a stable democratic government. In analyzing the possibility of receiving funds from the private sector, the finance team had to identify the investors both in the Philippines and from foreign countries. By examining the list of investment banks, the team was able to gather information about foreign investors in the Philippines and statistical data on investment in Metro Manila.

1) Investment Banks

According to data from the Bangko Sentral ng Pilipinas, or the Central Bank of the Philippines, there are eleven local banks and fourteen foreign banks in the Philippines. There is also a local bank, "the Metro Bank," that provides the loans for government agencies and public service companies by through support from the Development Bank of Singapore and Tokai Tokyo Financial Holding from Japan. Furthermore, there are also seven foreign banks that provide loans for large-scale development projects (Bangko Sentral ng Pilipinas, 2013).

\section{2) Foreign Investment}

According to the Philippines National Economic and Development Authority, there are six major trading partners of the Philippines: Japan, China, USA, Hong Kong, Singapore and Korea (see Table 5). In the Philippines, foreign investors are allowed to own 100\% of their firms, except for some business areas that are reserved for Filipinos or allow foreigners only to own some part of the firms(see Table 6) (NEDA, 2011).

Table 5. Philippines trading partners.

\begin{tabular}{|c|c|}
\hline Country/Region & Investment Area \\
\hline Japan & $\begin{array}{ll}\text { - } & \text { Manufacturing sector (automobiles, construction products and electronics) } \\
\text { - } & \text { Financial } \\
\text { - } & \text { Space technology }\end{array}$ \\
\hline China & $\begin{array}{ll}\text { - } & \text { Agricultural and manufacturing sectors } \\
\text { - } & \text { Ethanol and biodiesel plants } \\
\text { - } & \text { Mining industry } \\
\text { - } & \text { Tourist facilities }\end{array}$ \\
\hline USA & - $\quad$ Manufacturing sector (electronics and machinery) \\
\hline Hong Kong & $\begin{array}{ll}\text { - } & \text { Manufacturing sector (electronics and machinery) } \\
\text { - } & \text { Financial } \\
\text { - } & \text { Real estate }\end{array}$ \\
\hline Singapore & $\begin{array}{ll}\text { - } & \text { Manufacturing sector } \\
- & \text { Infrastructure and public private partnership (PPP) projects } \\
- & \text { Food and agribusiness } \\
\text { - } & \text { IT } \\
\text { - } & \text { Aircraft engineering services }\end{array}$ \\
\hline Korea & $\begin{array}{ll}\text { - } & \text { Financial } \\
\text { - } & \text { Engineering and construction services } \\
- & \text { Electronics } \\
\text { - } & \text { Food manufacturing } \\
\text { - } & \text { Energy }\end{array}$ \\
\hline
\end{tabular}

Source: National Economic Development Authority, 2011. 


\section{3) Investment in Metro Manila}

Of all industry in the Philippines, 36\% is owned by foreign investors, with the rest owned by local investors (see Table 7). Manufacturing and energy services are the sectors with the largest amount of investment.

\section{4) Conclusion}

From the above analysis, the finance team concludes with a final summary of funds separated into the three categories discussed, which are displayed in the following tables (Tables 8-10). Clearly, there is enough money in the government budget, foreign aid and direct foreign investment to fund the programs and projects suggested by the seven sectoral teams to implement the proposed environmental plan for Metro Manila.

Table 6. Restricted foreign investment industries.

\begin{tabular}{llll}
\hline \multicolumn{1}{c}{ Reserved for Filipinos Only } & Minority Foreign Ownership Allowed & Local Investors Encouraged \\
\hline - Mass media & - Financial institutions & \\
- Retail or trading & - Communication networks & - Security and defense related \\
- (paid-up capital less than \$2.5 million USD) & - Private recruitment & - & Public health and moral related \\
- Cooperatives & - Advertising & \\
\hline
\end{tabular}

Source: PWC, Philippines, 2015.

Table 7. Estimate for total investment 2016-2020 (Million USD).

\begin{tabular}{llllllll}
\hline Area & $\mathbf{2 0 1 4}$ & $\mathbf{2 0 1 5}$ & $\mathbf{2 0 1 6}$ & $\mathbf{2 0 1 7}$ & $\mathbf{2 0 1 8}$ & $\mathbf{2 0 1 9}$ & $\mathbf{2 0 2 0}$ \\
\hline Total & & 18,539 & 19,948 & 21,464 & 23,096 & 24,851 & 26,740 \\
Metro Manila & 3359 & 3615 & 3890 & 4185 & 4503 & 4846 & 5214 \\
Filipino Owned & 2150 & 2313 & 2489 & 2678 & 2882 & 3101 & 3337 \\
Foreign Owned & 1209 & 1301 & 1400 & 1506 & 1621 & 1744 & 1877
\end{tabular}

Source: Finance team.

Table 8. Government budget summary (Million USD).

\begin{tabular}{|c|c|c|c|c|c|}
\hline Group & 2016 & 2017 & 2018 & 2019 & 2020 \\
\hline Industry & 8.66 & 8.83 & 10.60 & 12.72 & 15.26 \\
\hline Energy & 5.08 & 5.19 & 6.22 & 7.47 & 8.96 \\
\hline Transportation & 93.05 & 94.92 & 96.81 & 98.75 & 100.72 \\
\hline Water & 5.36 & 5.46 & 5.57 & 5.68 & 5.80 \\
\hline Sewage and Sanitation & 6.72 & 6.86 & 6.99 & 7.13 & 7.28 \\
\hline Poverty Alleviation & 6.36 & 6.49 & 6.62 & 6.75 & 6.89 \\
\hline
\end{tabular}

Source: Finance team.

Table 9. Estimate of total foreign aid (USD).

\begin{tabular}{lll}
\hline Donors & Amount & Sector \\
Japan & $\$ 430$ Million USD & Transportation \\
China & $\$ 300$ Million USD & Transportation \\
World Bank & $\$ 100$ Million USD & Poverty Alleviation \\
& $\$ 1.5$ Million USD & Water \\
ADB & $\$ 350$ Million USD & Transportation \\
& $\$ 100$ Million USD & Water \\
United States & $\$ 100$ Million USD & Poverty Alleviation \\
Korea & $\$ 197$ Million USD total to the Philippines; & Transportation \\
\hline
\end{tabular}

Source: Finance team. 
Table 10. Project investors.

\begin{tabular}{|c|c|c|}
\hline Group & Local Investor & Foreign Investor \\
\hline Industry & $\begin{array}{ll}\text { - } & \text { Megawide } \\
\text { - } & \text { JG Summit Holding, INC. } \\
\text { - } & \text { SM Prime Holdings, Inc. } \\
\text { - } & \text { Cosco Capital, Inc. } \\
\text { - } & \text { GT Capital Holdings, Inc. } \\
\text { - } & \text { JG Summit Holdings, Inc. } \\
\text { - } & \text { Ayala Corporation } \\
\text { - } & \text { Cirtek Holdings Philippines Corporation }\end{array}$ & $\begin{array}{ll}\text { - } & \text { Japan } \\
\text { - } & \text { China } \\
\text { - } & \text { USA } \\
\text { - } & \text { Hong Kong } \\
\text { - } & \text { Singapore } \\
\text { - } & \text { Korea }\end{array}$ \\
\hline Energy & $\begin{array}{ll}\text { - } & \text { Meralco } \\
\text { - } & \text { National Grid Corporation of the Philippines } \\
\text { - } & \text { Aboitiz Power } \\
\text { - } & \text { Cosco Capital, Inc. } \\
\text { - } & \text { GT Capital Holdings, Inc. } \\
\text { - } & \text { JG Summit Holdings, Inc. } \\
\text { - } & \text { Ayala Corporation }\end{array}$ & $\begin{array}{ll}- & \\
\text { - } & \text { China } \\
& \text { Korea }\end{array}$ \\
\hline Transportation & $\begin{array}{ll}\text { - } & \text { Megawide } \\
\text { - } & \text { JG Summit Holding, INC. } \\
\text { - } & \text { JG Summit Holdings, Inc. } \\
\text { - } & \text { Ayala Corporation } \\
\text { - } & \text { Manila North Tollways }\end{array}$ & $\begin{array}{ll}\text { - } & \text { Japan } \\
\text { - } & \text { Singapore }\end{array}$ \\
\hline Water & $\begin{array}{ll}\text { - } & \text { Manila Water } \\
\text { - } & \text { JG Summit Holding, INC. } \\
\text { - } & \text { Ayala Corporation }\end{array}$ & $\begin{array}{ll}\text { - } & \text { Japan } \\
\text { - } & \text { Singapore } \\
\text { - } & \text { Korea }\end{array}$ \\
\hline Sewage and Sanitation & $\begin{array}{ll}\text { - } & \text { Megawide } \\
\text { - } & \text { Ayala Corporation }\end{array}$ & - $\quad$ Singapore \\
\hline Poverty Alleviation & $\begin{array}{ll}\text { - } & \text { Ayala Corporation } \\
\text { - } & \text { PLDT } \\
\text { - } & \text { Xurpas }\end{array}$ & - \\
\hline
\end{tabular}

Source: Finance team.

\section{Conclusion}

The intent of this project was to bring the contemporary thinking and practice of Urban Environmental Management to the solution of real problems in a major city in a developing country of Southeast Asia. The exercise, then, was to replicate as much as possible the conditions under which a team of expatriate consultants would operate in this context so that they could develop solutions that fit the circumstances they would likely find as professional planners working on such projects for international development banks (e.g., the World Bank, the Asian Development Bank, the Inter-American Development Bank or the African Development Bank), multilateral donors in the United Nations system such as the United Nations Development Program, or the numerous bilateral donors of the developed countries, which are primarily known by the alphabet soup of their initials. Major donor countries include the United States, Japan, Canada, Australia, United Kingdom, Germany, France, the Netherlands, Switzerland, Sweden, Denmark, Norway, Finland, Italy, Belgium and Spain. Consulting firms operating internationally on projects these institutions and countries fund come not only from the donor countries named, but increasingly from countries such as Brazil and India as well, and the staffs of experts they provide often come from a number of the countries named (Edelman, 2014).

In this working environment, it was instructive for the students to formulate a 5-year plan of solutions to the environmental problems and issues they faced rather than to be told how to solve them. This expanded their analytical skills and taught them how to utilize the limited knowledge and resources available to come up with implementable solutions for the benefit of the population of Metro Manila. They learned that such skills are transferable to other projects, and they gained a greater appreciation of the skill set that they are developing as planners. Bringing the reality of development to the classroom and asking students to confront it gives them an appreciation of professional practice that the study of theory alone does not. Thus, this project has attempted not only to expand the education of planning graduate students, but also to provide a meaningful contribution to planning pedagogy (Edelman, 2015). 


\section{References}

(2004). Philippines Sanitation Sourcebook.

(2007). Guidelines for the Implementation of the DOLE Worktrep Program, Department Order No. 81-07. http://www.dole.gov.ph/fndr/bong/files/DO\%2081-07.pdf

(2012). An Act Providing for the Security and Protection of Vendors in the Workplace and for Other Purposes. H. No. 968, 15th Cong. Retrieved from the Philippines' Congressional Database.

http://www.congress.gov.ph/download/basic_15/HB00968.pdf

(2013). An Act Providing for a Magna Carta for Workers in the Informal Economy, Institutionalizing Mechanisms for Implementation Thereof and for Other Purposes. H. No. 1955, 14th Cong. Retrieved from the Philippines' Congressional Database. http://www.congress.gov.ph/download/14th/hb01955.pdf

(2013). The Philippines Country Study.

(2014). https://quinsprogress.files.wordpress.com/2014/03/jeepney8.jpg

(2014). The Manila Times.

(2015). Economy of the Philippines. https://en.wikipedia.org/wiki/Economy of the Philippines

(2015). The Philippine Star.

Ajero, M. A. (2000). Future Emissions of Metro Manila.

Alave, K. (2011). Metro Manila Produces a Fourth of Philippine Garbage. Philippine Daily Inquirer.

Almendral, A. (2014). The Slum That Became Manila’s Recycling Champ. Next City.

Argo, Teti, Laquian, \& Aprodicio, A. (2011). Privatization of Water Utilities and Its Effects on the Urban Poor in Jakarta Raya and Metro Manila.

https://www.wilsoncenter.org/publication/privatization-water-utilities-and-its-effects-the-urban-poor-jakarta-raya-and-metro

Asian Development Bank (2011). Asian Development Bank and Philippines: Fact Sheet.

http://www.adb.org/publications/philippines-fact-sheet

Asian Development Bank (2011). Country Partnership Strategy: Philippines.

http://www.adb.org/sites/default/files/linked-documents/cps-phi-2011-2016-ssa-07.pdf

Asian Development Bank (2012). Philippines: Transport Sector Assessment, Strategy, and Roadmap.

Asian Development Bank (2014a). Asian Development Bank National Urban Assessment. https://openaccess.adb.org/bitstream/handle/11540/754/philippines-national-urban-assessment.pdf?sequence=1

Asian Development Bank (2014b). Tap Secrets: The Manila Water Story. Asian Development Bank. http://www.adb.org/publications/tap-secrets-manila-water-story

Asian Development Bank (2015). Philippines: Metro Manila Water and Sanitation Development Project. http://www.adb.org/projects/48173-003/main\#tabs-0-1

Asian Development Bank (ADB) (2012). Validation Report on Philippines: Pasig River Environmental Management and Rehabilitation Sector Development Program, 1-7. http://www.adb.org/sites/default/files/evaluationdocument/36027/files/pvr-187.pdf

Asian Development Bank (ADB) (2013). Philippines: Water Supply and Sanitation Sector Assessment, Strategy, and Road Map, 1-37.

Bangko Sentral ng Pilipinas (2013). Media Releases. BangkoSentral ng Pilipinas. http://www.bsp.gov.ph/publications/media.asp?id=3245

Bangko Sentral ng Pilipinas (2015). Invest Philippines. Republic of Philippines. http://investphilippines.gov.ph/

Bernardo, E. C. (2008). Solid-Waste Management Practices of Households in Manila, Philippines. Annals of the New York Academy of Sciences, 1140, 420-424. http://dx.doi.org/10.1196/annals.1454.016

Bonnin, C. L. (2004). Windows to the Market; Exploring Women's Strategies and Supports as Home-Based Traders in Metro Manila (Unpublished master's dissertation). Halifax: Dalhousie University.

Brookings Institution. (2015). Global Metro Monitor. http://www.brookings.edu/research/reports2/2015/01/22-global-metro-monitor

Buco, B., \& Buco Jr., B. V. (2009). Manila Traffic Found Costing Economy \$2 Billion Each Year. San Juan: Business World.

Buentjen, C. (2011). Philippines 2011-2016 Country Partnership Report for the Asian Development Bank. http://www.adb.org/sites/default/files/institutional-document/33024/files/cps-phi-2011-2016.pdf 
Casanova-Dorotan, F. G. (2010). Informal Economy Budget Analysis in the Philippines and Quezon City. http://wiego.org/sites/wiego.org/files/publications/files/Casanova-Dorotan_WIEGO_WP12.pdf

Central Intelligence Agency, World Factbook. (2015). https://www.cia.gov/library/publications/the-world-factbook/fields/2116.html

Cities Alliance (2007). Liveable Cities: The Benefits of Urban Environmental Planning: A Cities Alliance Study on Good Practices and Useful Tools. Cities Alliance. http://www.unep.org/urban_environment/pdfs/liveableCities.pdf

Dancel, R. (2015). Philippines Sees Slow Take Up of Renewable Energy. The Guardian. http://www.theguardian.com/environment/2015/jun/18/philippines-sees-slow-take-up-of-renewable-energy

Demographia (2015). Demographia World Urban Areas (11th ed.). http://www.demographia.com/db-worldua.pdf

Department of Energy (2008). Philippine Energy Situation.

Department of Public Works and Highways (n. d.). Annual Budget. http://www.dpwh.gov.ph/about_us/financial.htm

Desai, P. and Riddlestone, S. (2002). Bioregional Solutions for Living on One Planet. Bristol: Green Books Ltd. for the Schumacher Society.

Donaldson, D., Sader, F., \& Wagle, D. M. (1997). Foreign Direct Investment in Infrastructure: The Challenge of Southern and Eastern Africa. World Bank Publications. http://dx.doi.org/10.1596/0-8213-3885-4

Dorell, O. (2013). China Lags Ikea in Aid to Philippines. USA Today. http://www.usatoday.com/story/news/world/2013/11/14/china-typhoon-haiyan-aid/3529729/

Edelman, D. (Ed.) (2014). Managing the Urban Environment-Mysore, India. Saarbrücken: LAP LAMBERT Academic Publishing.

Edelman, D. (Ed.) (2015). Managing the Urban Environment-Lagos, Nigeria. Saarbrücken: LAP LAMBERT Academic Publishing.

Elloso, R. (2013). The Perennial Problem of Garbage. Manila Bulletin. http://www.mb.com.ph/the-perennialproblem-of-garbage/

Environment and Natural Disasters (n. d.). http://www.investphilippines.info/arangkada/climate/environment-and-natural-disasters/

Espiritu, R. (2011). Maynilad Water District, Philippines. http://www.un.org/waterforlifedecade/green_economy_2011/pdf

Flor, D., \& Javier, S. (n. d.). Philippine Transportation Statistics. National Center for Transportation Studies. http://www.kokudokeikaku.go.jp/wat2/22_philippines.pdf

Frianeza, M. P. (2012). Women in the Informal Sector in the Philippines. Review of Women's Studies, 13.

Gaillard, J. C., \& Cadag, J. R. D. (2009). From Marginality to Further Marginalization: Experiences from the Victims of the July 2000 Payatas Trashslide in the Philippines. JAMBA: Journal of Disaster Risk Studies, 2, 197-215. http://dx.doi.org/10.4102/jamba.v2i3.27

Girardet, H. (1999). Creating Sustainable Cities. Totnes, Devon: Green Books for the Schumacher Society.

Grameen Foundation (2013). Building Sustainable Business Models for Providing Financial Services to the Poor. http://www.grameenfoundation.org/resource/building-sustainable-businessmodels-providing-financial-services-poor

Hendricks, L., \& Chidiac, S. (2011). Village Savings and Loans: A Pathway to Financial Inclusion for Africa's Poorest Households. Valladolid: Commissioned Workshop Paper Presented at the Meeting of the 2011 Global Microcredit Summit.

Illy, H. F. (1986). Regulation and Evasion: Street-Vendors in Manila. Policy Sciences, 19, 61-81. http://dx.doi.org/10.1007/BF02124484

Japan International Cooperation Agency (n. d.). Activities in the Philippines. JICA. http://www.jica.go.jp/philippine/english/activities/activity01.html

Jinoh, K. (n. d.). Korea’s Grant Aid Assistance to the Philippines. Forging a New Philippines Foreign Policy. http://www.philippinesintheworld.org/sites/default/files/Korea\%27s\%20Grant\%20Aid\%20Assistance\%20to\%20the\%20P hilippines KOICA.pdf

Kapit Bisig Para Sailog Pasig (n. d.). http://kapitbisigparasailogpasig.com/

Lee, A. (2014). Business Process Outsourcing in the Philippines. Lee Kuan Yew School of Public Policy, National University of Singapore.

Lumampao, F. (2004). Enabling Urban Poor Livelihoods Policy Making: Understanding the Role of Energy Services. The Netherlands: Technical University of Twente. 
Manila Bulletin (2015). Philippines Is Poised to be "BPO Capital of the World”-CBRE. http://www.mb.com.ph/philippines-poised-to-be-bpo-capital-of-the-world-cbre/

Manila Capacity Expanded (2007). Railway Gazette International, 163, 8.

Maynilad Water Services Inc. (2010). Press Releases. Maynilad Water. http://www.mayniladwater.com.ph/news-article.php?id=102

MERALCO. (2015). Understanding Your Bill.

Merry, S. M., Kavazanjian, E., \& Fritz, W. U. (2005). Reconnaissance of the July 10, 2000, Payatas Landfill Failure. Journal of Performance of Constructed Facilities, ASCE, 19, 100-107. http://dx.doi.org/10.1061/(ASCE)0887-3828(2005)19:2(100)

Mouton, M. (2015). The Philippine Electricity Sector Reform and the Urban Question: How Metro Manila’s Utility Is Tackling Urban Poverty. Energy Policy, 78, 225-234. http://dx.doi.org/10.1016/j.enpol.2014.11.005

Murakami, A., \& Palijon, A. M. (2005). Urban Sprawl and Land Use Characteristics in the Urban Fringe of Metro Manila, Philippines. Journal of Asian Architecture and Building Engineering, 4, 177-183. http://dx.doi.org/10.3130/jaabe.4.177

Nakamura, S. (2009). Spatial Analysis of Urban Poverty in Manila, Philippines. (Unpublished Project). Ithaca, NY: Cornell University.

National Economic Development Authority (NEDA) (2011). Philippine Development Plan 2011-2016. http://www.neda.gov.ph/2013/10/21/philippine-development-plan-2011-2016/

National Power Corporation (2014). Bataan Nuclear Power Plant. http://www.napocor.gov.ph/index.php/bataan-nuclear-power-plant

Newsbytes (2014). Accenture, Convergys Top Revenue Earners in BPO Space: Solon. http://newsbytes.ph/2014/12/06/accenture-convergys-top-revenue-earners-in-bpo-space-solon/

OECD (2015). DAC Criteria for Evaluating Development Assistance. http://www.oecd.org/dac/evaluation/daccriteriaforevaluatingdevelopmentassistance.htm

Oxford Business Group (2015). The Philippines Economy Slowing but Steady.

Paje, R. (2011). State of the Environment-Investment Prospects. http://www.slideshare.net/arangkadaph/state-of-the-philippine-environment?next_slideshow=2

Pascual, F. (2013). Bataan Nuclear Power Plant: Reopen It or Not? The Philippine Star. http://www.philstar.com/opinion/2013/08/06/1057341/bataan-nuclear-power-plant-reopen-it-or-not

Petilla, C. J. L. (2013). Electric Power Supply-Demand Outlook for 2012-2030.

Philippine Atmospheric Administration (PAGASA) (2015). Climate of the Philippines. https://kidlat.pagasa.dost.gov.ph/index.php/clinate-of-the-philippines

Philippines Bureau of Internal Revenue (BIR) (2015).

Philippines Department of Budget and Management (DBM) (2015).

Pollution Prevention (P2) (n. d.).

Porio, E. (2011). Vulnerability, Adaptation, and Resilience to Floods and Climate Change-Related Risks among Marginal, Riverine Communities in Metro Manila. Asian Journal of Social Science, 39, 425-445. http://dx.doi.org/10.1163/156853111X597260

Porio, E. (2011). Vulnerability, Adaptation, and Resilience to Floods and Climate Change-Related Risks among Marginal, Riverine Communities in Metro Manila. Asian Journal of Social Science, 39, 425-445. http://dx.doi.org/10.1163/156853111X597260

Porio, E. (2012). Decentralization, Power and Networked Governance Practices in Metro Manila. Space and Polity, $16,7-27$. http://dx.doi.org/10.1080/13562576.2012.698128

Price Waterhouse Coopers, Inc. (PWC), Philippines (2015).

Programa Vivenda (2015). http://programavivenda.com.br/\#main_header

Ragragio, J. M. (2003). Understanding Slums: Case Studies for the Global Report 2003, Manila, Philippines. http://www.ucl.ac.uk/dpu-projects/Global_Report/cities/manila.htm

Ranada, P. (2015). 355,500 Homes in NCR Face Water Disruption starting September. http://www.rappler.com/nation/104371-metro-manila-homes-water-disruption-el-nino

Reyes, E. (2013). Energy Efficiency in the Philippines. 
Robles, A. C. (2012). The Agony of Metro Manila Commuters. GMA News Online.

http://www.gmanetwork.com/news/story/254898/news/specialreports/the-agony-of-metro-manila-commuters

Romualdez, B. G. (2015). Bright Prospects for BPO Industry. Philstar.

http://www.philstar.com/business/2015/02/10/1421942/bright-prospects-bpo-industry

Royal Commission on Environmental Pollution (2007). The Urban Environment. Twenty-Sixth Report Presented to Parliament by Command of Her Majesty.

https://www.gov.uk/government/uploads/system/uploads/attachment_data/file/228911/7009.pdf

Sahakian, M. D. (2011). Understanding Household Energy Consumption Patterns: When "West Is Best” in Metro Manila. Energy Policy, 39, 596-602. http://dx.doi.org/10.1016/j.enpol.2010.10.032

Steele, G., Avila, J., Miller, D., \& Britan, G. (2014). Ending Extreme Poverty in the Philippines through Urban-Led Growth. In R. Shah, \& N. Unger (Eds.), Frontiers of Development, End Extreme Poverty (pp. 82-87). Agency for International Development US. https://www.usaid.gov/sites/default/files/documents/1870/USAID Frontiers in Development 2014.pdf

Sticzay, N., \& Koch, L. (2015). Slum Upgrading. https://sustainabledevelopment.un.org/content/documents/5754Slum\%20Upgrading.pdf

Storey, D. (2012). Manila, Philippines. In C. Zimring, \& W. Rathje (Eds.), Encyclopedia of Consumption and Waste: The Social Science of Garbage (pp. 499-502). Thousand Oaks, CA: SAGE Publications, Inc. http://dx.doi.org/10.4135/9781452218526.n194

The Borgen Project (2013). Latest Statistics on Philippine Poverty. http://borgenproject.org/latest-statistics-on-philippine-poverty/

Transparency International (2014). Corruption Perceptions Index. http://www.transparency.org/cpi2014/infographic

Troilo, P. (2011). Top 10 Foreign Aid Donors to the Philippines. Devex. https://www.devex.com/news/top-10-foreign-aid-donors-to-the-philippines-76515

United Nations Development Programme (UNDP) (2006). Beyond Scarcity: Power, Poverty, and the Global Water Crisis. Human Development Report 2006. Hoechestetter Printing Co.

United States Agency for International Development (2015). US Overseas Loans and Grants to Philippines. Inside Gov. http://us-foreign-aid.insidegov.com/l/139/Philippines

Urban Management Program of the World Bank (1997). Household Responses to Poverty and Vulnerability (Vol. 4). Washington DC: Caroline Moser and Cathy McIlwaine.

USAID Land Tenure and Property Rights Portal (2014). USAID. http://www.usaidlandtenure.net/project/mobile-application-secure-tenure-tanzania

VSL Associates (2015). Reaching the Poor: The Need for a New Microfinance Model. http://www.vsla.net/

Water Environment Partnership in Asia (n. d.).

Webber, M. M. (1973). Dilemmas in a General Theory of Planning. Policy Sciences, 4, 155-169. http://dx.doi.org/10.1007/BF01405730

Wootton, M. (2013). Renewable Energy in the Philippines. http://www.energybiz.com/article/13/06/renewable-energy-philippines

Work Bank Annual Report (2011). http://web.worldbank.org/WBSITE/EXTERNAL/EXTABOUTUS/EXTANNREP/EXTANNREP2011/0,,contentMDK:22 969490 menuPK:8121330 pagePK:64168427 piPK:64168435 theSitePK:8070617,00.html

World Bank (2004). Beyond Economic Growth. The World Bank. http://www.worldbank.org/depweb/beyond/beyondco/beg_13.pdf

World Bank (2011). Philippines: World Bank Approves \$1.5M Grant for Metro Manila’s Flood Control Master Plan. Relife Web.

http://reliefweb.int/report/philippines/philippines-world-bank-approves-15m-grant-metro-manilas-flood-control-master-plan

World Bank (2015). Philippines. The World Bank. http://www.worldbank.org/en/country/philippines/projects

World Bank. (2011). Implementation Completion and Results Report (BRD-70580 TF 29804) on a Loan in the Amount of US \$60 Million and a Global Environmental Facility Grant in the Amount of SDR 1.0 million (US \$ 1.3 Million Equivalent) to the Republic of the Philippines for the Metro Manila Urban Transport Integration Project.

Wrona, N. (2014). Can Manila Turn into a Zero-Waste City? Waste Dive.

http://www.wastedive.com/news/canmanila-turn-into-a-zero-waste-city/244112/ 